\title{
Palladium(II) Complexes Containing a Pyridinyliminophosphorane Ligand
}

\author{
Hung-Ren Wu, ${ }^{\text {[a] }}$ Yi-Hung Liu, ${ }^{\text {[a] }}$ Shie-Ming Peng, ${ }^{\text {[a] }}$ and Shiuh-Tzung Liu*[a]
}

Keywords: N ligands / Polymerization / Palladium

A series of new pyridinyliminophosphorane bidentate ligands with different steric environments $\left[\left(2-\mathrm{C}_{6} \mathrm{H}_{4} \mathrm{~N}\right) \mathrm{PPh}_{2}=\right.$ NAr (NPN)] and their methylpalladium complexes [PdClMe(NPN)] were prepared. From the crystal structure analysis it is evident that the alkyl ligands are always trans to the pyridinyl nitrogen donor, revealing a $\sigma$-donating abil- ity of the iminophosphorane. However, the two $\mathrm{Pd}-\mathrm{Cl}$ bonds in $\left[\mathrm{PdCl}_{2}(\mathbf{N P N})\right]$ are essentially the same length. Cationic palladium complexes catalyzed the copolymerization of norbornene/ethylene as well as $\mathrm{CO} /$ norbornene.

(c) Wiley-VCH Verlag GmbH \& Co. KGaA, 69451 Weinheim, Germany, 2003)

\section{Introduction}

Since the discovery of highly active diiminopalladium complexes for the polymerization of olefins under mild conditions by Brookhart's group, ${ }^{[1]}$ the design of new ligands to fine-tune the activity of catalysts has received much attention. ${ }^{[2]}$ It is documented that the steric bulkiness around the active metal center favors chain propagation, leading to higher molecular-weight and branched polymers. ${ }^{[1,2]}$ Another attractive feature in this area is the possibility of employing late transition metal complexes, containing heterodonor systems, since the olefin insertion into the $\mathrm{M}-\mathrm{C}$ bond can be governed by the electronic properties of donor atoms. ${ }^{[2]}$ Presumably due to the reactivity of iminophosphoranes toward moisture ${ }^{[3]}$ and carbonyl groups ${ }^{[4]}$ the use of this kind of donor in catalytic polymerization is less-well explored. ${ }^{[5]}$ Recently, Stephan and Collins' groups have reported independently that early transition metal complexes with phosphinimide ligands can catalyze the polymerization of ethylene. ${ }^{[6,7]}$ While the coordination studies involving iminophosphorane toward late transition metal complexes are well-examined, ${ }^{[4 \mathrm{c}, 8-12]}$ we would like to contribute our efforts in this area by investigating the behavior of palladium complexes with a series of bidentate pyridinyliminophosphorane ligands as well as their catalytic polymerization activity toward olefins.

\section{Results and Discussion}

\section{Preparation of Complexes}

The ligands $\left(\mathbf{L}_{\mathbf{a}}-\mathbf{L}_{\mathbf{c}}\right)$ were prepared in high yield by the Staudinger reaction of 2-diphenylphosphanylpyridine with

[a] Department of Chemistry, National Taiwan University, Taipei, Taiwan 106, ROC

Fax: (internat.) +886-2/2363 6359

E-mail: stliu@ntu.edu.tw the corresponding aryl azide under anhydrous conditions (Scheme 1). Substitution reactions of [PdClMe(COD)] with pyridine-iminophosphorane (NPN) in dichloromethane at room temperature readily led to the formation of bidentate palladium complexes $(\mathbf{1 a}-\mathbf{c})$, which were treated with $\mathrm{AgBF}_{4}$ to yield the corresponding cationic species $(\mathbf{2} \mathbf{a}-\mathbf{c}$; Scheme 1). All the palladium complexes were isolated as solids and were stable in solution under a nitrogen atmosphere.
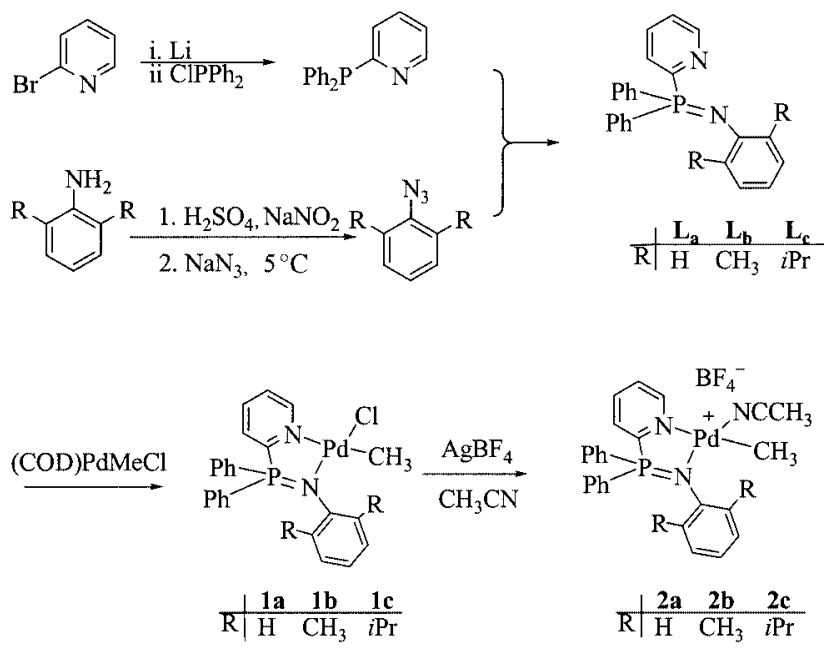

Scheme 1. Preparation of ligands and palladium complexes

In the NMR spectra of the ligands $\mathbf{L}_{\mathbf{a}}-\mathbf{L}_{\mathbf{c}}$ and of the palladium complexes $\mathbf{1 a - 2}$, differences between the substituents on the benzene rings were observed. The ${ }^{1} \mathrm{H},{ }^{13} \mathrm{C}$ and ${ }^{31} \mathrm{P}$ NMR resonances of these related species are quite similar as shown in Table 1, and are consistent with the expected structure. It can also be seen that the ${ }^{31} \mathrm{P}$ NMR spec- 
Table 1. Selected spectroscopic data of ligands and complexes

\begin{tabular}{|c|c|c|c|c|c|}
\hline \multirow[t]{2}{*}{ Compound } & \multicolumn{3}{|c|}{${ }^{1} \mathrm{H} \mathrm{NMR}^{[\mathrm{a}]}$} & \multirow{2}{*}{$\begin{array}{l}{ }^{31} \mathrm{P} \text { NMR } \\
\mathrm{Pd}-\mathrm{CH}_{3}\end{array}$} & \multirow{2}{*}{${ }^{13} \mathrm{C} \mathrm{NMR}$} \\
\hline & Рy- $H-6$ & $\mathrm{Pd}-\mathrm{NCCH}_{3}$ & $\mathrm{Pd}-\mathrm{CH}_{3}$ & & \\
\hline $\mathbf{L}_{\mathbf{a}}$ & $8.78(\mathrm{~d}, J=4.6)$ & - & - & 14.7 & - \\
\hline $\mathbf{L}_{b}$ & $8.75(\mathrm{~d}, J=4.8)$ & - & - & 16.5 & - \\
\hline $\mathbf{L}_{\mathbf{c}}$ & $8.84(\mathrm{~d}, J=4.0)$ & - & - & 15.6 & - \\
\hline $1 \mathrm{a}$ & $9.03(\mathrm{~d}, J=4.5)$ & - & 0.77 & 26.6 & -3.0 \\
\hline 1b & $9.35(\mathrm{~d}, J=5.1)$ & - & 0.60 & 21.7 & -5.79 \\
\hline 1c & $9.47(\mathrm{~d}, J=5.1)$ & - & 0.69 & 22.5 & -2.88 \\
\hline $2 a$ & $9.03(\mathrm{~d}, J=4.7)$ & 2.44 & 0.69 & 34.3 & 1.12 \\
\hline $2 \mathrm{~b}$ & $9.02(\mathrm{~d}, J=5.1)$ & 2.42 & 0.55 & 30.3 & 3.20 \\
\hline $2 \mathrm{c}$ & $9.13(\mathrm{~d} . J=4.7)$ & 3.19 & 0.58 & 31.7 & 1.66 \\
\hline
\end{tabular}

[a] Coupling constant $J$ (in $\mathrm{Hz}$ ).

tra for $\mathbf{1 a - 2 c}$ show only one signal for each complex, indicating that one single stereoisomer was formed upon complexation. Fortunately, the detailed structures of $\mathbf{1 b}, \mathbf{1 c}$ and 2a were further confirmed by a crystal structure analysis, which showed clearly the stereo relationship of the donors around the palladium center.

Single crystals suitable for the analysis of the complexes 1b, 1c and $\mathbf{2 a} \cdot \mathbf{C} \mathbf{H}_{\mathbf{2}} \mathbf{C l}_{\mathbf{2}}$ were obtained by slow evaporation of dichloromethane/diethyl ether solutions. The crystal data of these complexes are collected in Table 2. ORTEP plots of $\mathbf{1 b}, \mathbf{1 c}$ and $\mathbf{2} \mathbf{a} \cdot \mathbf{C} \mathbf{H}_{\mathbf{2}} \mathbf{C l}_{\mathbf{2}}$ are depicted in Figures $1-3$, respectively, and selected bond lengths and angles are summarized in Table 3. All the palladium complexes are square planar with slight distortions, particularly for the angle $\mathrm{N}(1)-\mathrm{Pd}-\mathrm{N}(2)\left(\mathrm{ca} .84^{\circ}\right)$. In all instances, the methyl group is located trans to the pyridinyl-nitrogen and the $\mathrm{Pd}-\mathrm{C}$ distances are in the range $2.000-2.114 \AA$, which are typical palladium-methyl carbon lengths. ${ }^{[13]}$ Examination of

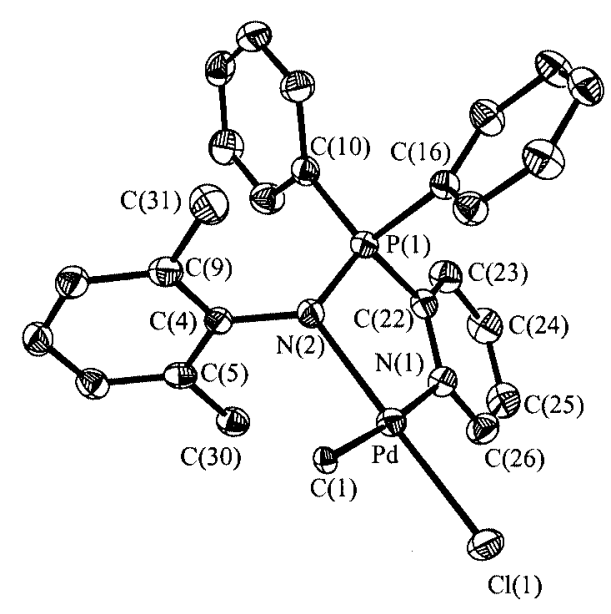

Figure 1. ORTEP plot of the cationic part of complex $\mathbf{1 b}$

Table 2. Selected crystallographic data of complexes $\mathbf{1 b}, \mathbf{1 c}, \mathbf{2 a}$ and $\mathbf{5}$

\begin{tabular}{|c|c|c|c|c|}
\hline Complex & $2 a$ & $1 b$ & 1c & 5 \\
\hline Formula & $\mathrm{C}_{27} \mathrm{H}_{27} \mathrm{BCl}_{2} \mathrm{~F}_{4} \mathrm{~N}_{3} \mathrm{PPd}$ & $\mathrm{C}_{26} \mathrm{H}_{26} \mathrm{ClN}_{2} \mathrm{PPd}$ & $\mathrm{C}_{30} \mathrm{H}_{34} \mathrm{ClN}_{2} \mathrm{PPd}$ & $\mathrm{C}_{25} \mathrm{H}_{23} \mathrm{Cl}_{2} \mathrm{~N}_{2} \mathrm{PPd}$ \\
\hline Mol. wt. & 688.60 & 539.31 & 595.41 & 559.72 \\
\hline Crystal system & triclinic & monoclinic & monoclinic & monoclinic \\
\hline Space group & $P \overline{1}$ & $P 2_{1} / n$ & $\mathrm{Cc}$ & $\mathrm{Cc}$ \\
\hline$a(\AA)$ & $8.2500(1)$ & $9.5805(1)$ & $10.7780(6)$ & $9.3350(1)$ \\
\hline$b(\AA)$ & $12.3890(1)$ & $14.6296(2)$ & $17.474(1)$ & $17.2460(2)$ \\
\hline$c(\AA)$ & $15.4960(2)$ & $16.6491(3)$ & $15.0640(9)$ & $15.2670(2)$ \\
\hline$\alpha\left(^{\circ}\right)$ & $74.300(1)$ & 90 & 90 & 90 \\
\hline$\beta\left(^{\circ}\right)$ & $87.674(1)$ & $98.8701(6)$ & $91.986(3)$ & $104.798(1)$ \\
\hline$\gamma\left({ }^{\circ}\right)$ & $82.592(1)$ & 90 & 90 & 90 \\
\hline$V\left(\AA^{3}\right)$ & $1511.99(3)$ & $2305.61(6)$ & $2835.4(3)$ & $2376.33(5)$ \\
\hline$Z$ & 2 & 4 & 4 & 4 \\
\hline$D_{\text {calcd }}\left(\mathrm{Mg} / \mathrm{m}^{3}\right)$ & 1.512 & 1.554 & 1.395 & 1.565 \\
\hline$F(000)$ & 692 & 1096 & 1224 & 1128 \\
\hline Crystal size (mm) & $0.35 \times 0.30 \times 0.25$ & $0.20 \times 0.10 \times 0.07$ & $0.25 \times 0.20 \times 0.10$ & $0.25 \times 0.20 \times 0.15$ \\
\hline$\theta$ range & $2.47-25.00$ & $2.31-27.50$ & $2.22-27.50$ & $2.36-27.47$ \\
\hline Refln collected & 9984 & 32976 & 9688 & 27038 \\
\hline Independent refln. & $5314\left(R_{\mathrm{i} n \mathrm{t}}=0.0206\right)$ & $5305\left(R_{\mathrm{i} n \mathrm{t}}=0.0695\right)$ & $5748\left(R_{\mathrm{i} n \mathrm{t}}=0.0713\right)$ & $5396\left(R_{\mathrm{i} n \mathrm{t}}=0.0449\right)$ \\
\hline Refinement method & $\begin{array}{l}\text { Full-matrix least-squares } \\
\text { on } F^{2}\end{array}$ & & & \\
\hline $\mathrm{R}[I>2 \sigma(I)]$ & $\begin{array}{l}R_{1}=0.0418 \\
w R_{2}=0.1194\end{array}$ & $\begin{array}{l}R_{1}=0.0371 \\
w R_{2}=0.0900\end{array}$ & $\begin{array}{l}R_{1}=0.0568 \\
w R_{2}=0.1329\end{array}$ & $\begin{array}{l}R_{1}=0.0300 \\
w R_{2}=0.0714\end{array}$ \\
\hline
\end{tabular}




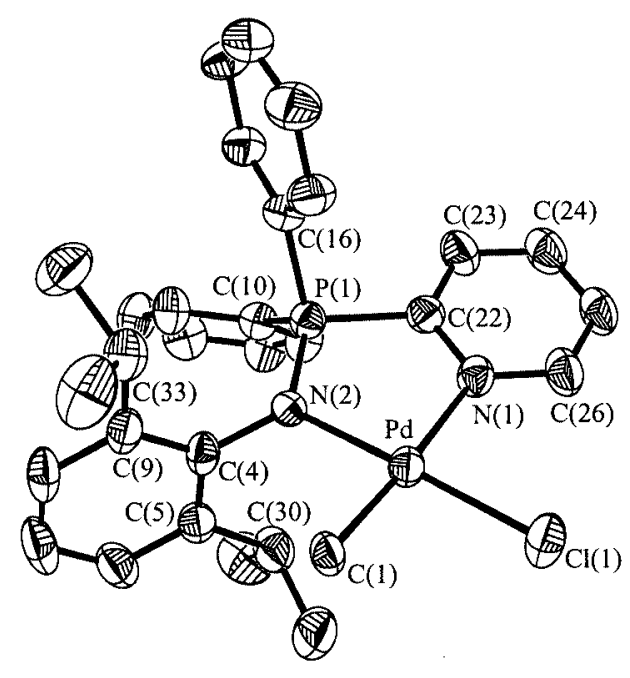

Figure 2. Molecular structure of 1c

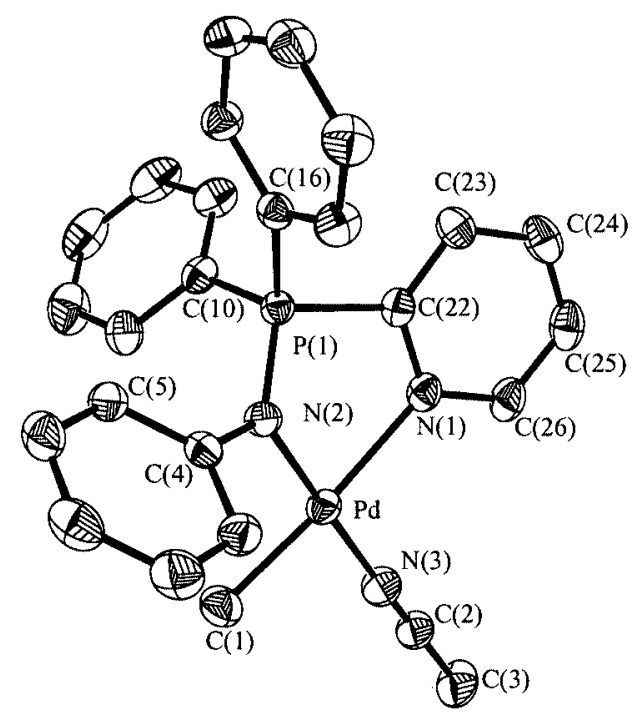

Figure 3. ORTEP drawing of 2a

$\mathrm{Pd}-\mathrm{N}(2)-\mathrm{C}(4), \mathrm{Pd}-\mathrm{N}(2)-\mathrm{P}(1)$ and $\mathrm{P}(1)-\mathrm{N}(2)-\mathrm{C}(4)$ reveals that the $\mathrm{N}(2)$ center is trigonal planar, indicating an $\mathrm{sp}^{2}$ hybridization of the nitrogen atom. All other bond lengths and bond angles lie within the usual range even in the case of $1 \mathbf{c}$, with the bulky substituents on the aryl ring. However, the dihedral angles of $\mathrm{N}(1)-\mathrm{C}(22)-\mathrm{P}(1)-\mathrm{N}(2)$ and the orientation of the imine $[\mathrm{N}(2)]$ aryl ring relative to the chelating ring appear to be the major differences among these crystal structures.

The small dihedral angles of $\mathrm{N}(1)-\mathrm{C}(22)-\mathrm{P}(1)-\mathrm{N}(2)$ for 1c $\left[6.1(6)^{\circ}\right]$ imply an almost planar geometry for this bidentate ligand, whereas a larger deviation of this angle from planar geometry in both 2a and 1b [2a: 26.9(3) ${ }^{\circ}$; 1b: $\left.28.3(3)^{\circ}\right]$ is observed. In fact, the chelating ring in $\mathbf{1 c}$ lies in a plane with a slight deviation of $\mathrm{N}(2)$ by ca. $0.12 \AA$, based on the calculated plane defined by $\mathrm{P}(1)-\mathrm{C}(22)-\mathrm{N}(1)-\mathrm{Pd}$. The dihedral angle between the chelating ring and the imino $[\mathrm{N}(2)]$ aryl ring for $\mathbf{1} \mathbf{c}$ is $82.6(2)^{\circ}$, showing that the isopropyl groups on the aryl ring readily force this ring to lie almost perpendicular to the chelating ring in order to relieve the steric interaction between the ring substituents and the coordinated ligands.

A simple comparison of a few methylpalladium chloride complexes is summarized in Scheme 2. Several differences between these structures are: (1) the $\mathrm{Pd}-\mathrm{Cl}$ bond trans to the phosphane donor is slightly longer than the bonds trans to the nitrogen donors. (2) The $\mathrm{Pd}-\mathrm{C}$ bond of $\mathbf{1 c}$ is longer by ca. $0.1 \AA$ than the bonds in $[\operatorname{PdClMe}(\mathbf{P} \sim \mathbf{N})]$ and $[\operatorname{PdClMe}(\mathbf{N} \sim \mathbf{N})]$. (3) The bite angle decreases in the order: 1c $<[\operatorname{PdClMe}(\mathbf{P} \sim \mathbf{N})]<[\operatorname{PdClMe}(\mathbf{N} \sim \mathbf{N})]$. The shorter length of $\mathrm{Pd}-\mathrm{N}(2)$ in 1c indicates a stronger coordination of the nitrogen donor to palladium, thus showing that the iminophosphorane functionality remains intact. Indeed, the palladium complexes $\mathbf{1 a}-\mathbf{c}$ are fairly stable towards air or even moisture. In NMR investigations, complexes $\mathbf{2 a}-\mathbf{c}$ remain unchanged for several days in the presence of water with trace amounts of coordinating acetonitrile replaced by water molecules. It is known that the iminophosphorane moiety undergoes $\mathrm{P}-\mathrm{N}$ bond cleavage with water, ${ }^{[3]}$ but such activity is readily hindered by the chelation upon complexation, which is quite similar to that reported by Réau in palladium complexes containing 1,2-bis(triphenylphosphinimino)cyclohexane. ${ }^{[8]}$

\section{Insertion of Carbon Monoxide and Ethylene}

The insertion of carbon monoxide into the $\mathrm{Pd}-\mathrm{C}$ bond of compounds $\mathbf{2 a}-\mathbf{c}$ was studied (Scheme 3 ). A dichloromethane solution of the individual complex was bubbled with $\mathrm{CO}$ and monitored by ${ }^{31} \mathrm{P}$ NMR spectroscopy. All three complexes, $\mathbf{2 a}-\mathbf{c}$, underwent insertion to yield the corresponding acyl complexes and the insertion rate followed the order of the less steric environments $(2 \mathbf{a}>\mathbf{2 b}>$ 2c), as evidenced by NMR spectroscopy. The resulting acyl complexes $\mathbf{3 b}$ and $\mathbf{3 c}$ were isolated in stable solid form, whereas the inserted product 3a readily decomposed in the absence of a carbon monoxide atmosphere. Selected spectroscopic data are summarized in Table 4. The presence of the ${ }^{13} \mathrm{C}$ chemical shift at $\delta=220 \mathrm{ppm}$ and the infrared stretching frequency around $1700 \mathrm{~cm}^{-1}$ clearly demonstrate the formation of the acetyl group.

Subsequent insertion of ethylene into the Pd-acyl bond of $\mathbf{3 b}-\mathbf{c}$ can be achieved by bubbling ethylene gas through a dichloromethane solution of the respective palladium complex. The inserted products $\mathbf{4 b}-\mathbf{c}$ were obtained as airstable yellow solids and the spectroscopic data (Table 4) clearly support the structure proposed. The carbonyl stretching frequency in the range of $1600-1630 \mathrm{~cm}^{-1}$ for $\mathbf{4 b}-\mathbf{c}$ suggests that the formation of the five-membered $(\mathrm{C}, \mathrm{O})$ chelate ring provides extra stability for these complexes. ${ }^{[13]}$

\section{Complex $\left[\operatorname{PdCl}_{2}\left(\mathrm{~L}_{\mathrm{b}}\right)\right]$}

In order to find out the difference in the trans influence between pyridinyl and iminophosphorane nitrogen, the palladium dichloride complex $\left[\mathrm{PdCl}_{2}\left(\mathbf{L}_{\mathbf{b}}\right)\right](\mathbf{5})$ was prepared by 
Table 3. Selected bond lengths ( $\mathrm{A})$ and angles (deg) for $\mathbf{1 b}, \mathbf{1 c}, \mathbf{2 a}$ and $\mathbf{5}$

\begin{tabular}{lcccc}
\hline Complex & $\mathbf{2 a}, \mathrm{X}=\mathrm{N}(3)$ & $\mathbf{1 b}, \mathrm{X}=\mathrm{Cl}(1)$ & $\mathbf{1 c}, \mathrm{X}=\mathrm{Cl}(1)$ & $\mathbf{5 , X}=\mathrm{Cl}(1)$ \\
\hline $\mathrm{Pd}-\mathrm{N}(1)$ & $2.173(3)$ & $2.160(7)$ & $2.170(3)$ & $2.070(3)$ \\
$\mathrm{Pd}-\mathrm{N}(2)$ & $2.052(3)$ & $2.090(6)$ & $2.080(3)$ & $2.048(3)$ \\
$\mathrm{Pd}-\mathrm{C}(1)$ & $2.008(4)$ & $2.114(7)$ & $2.087(3)$ & $\mathrm{Pd}-\mathrm{Cl}(2): 2.291(1)$ \\
$\mathrm{Pd}-\mathrm{X}$ & $2.005(3)$ & $2.302(2)$ & $2.3085(8)$ & $2.2877(9)$ \\
$\mathrm{P}(1)-\mathrm{N}(2)$ & $1.597(3)$ & $1.595(6)$ & $1.592(3)$ & $1.590(3)$ \\
$\mathrm{P}(1)-\mathrm{C}(22)$ & $1.824(3)$ & $1.820(8)$ & $1.819(3)$ & $1.834(3)$ \\
$\mathrm{C}(22)-\mathrm{N}(1)$ & $1.337(5)$ & $1.36(1)$ & $1.354(4)$ & $1.340(5)$ \\
$\mathrm{N}(2)-\mathrm{C}(4)$ & $1.424(4)$ & $1.435(9)$ & $1.428(4)$ & $1.426(4)$ \\
$\mathrm{N}(1)-\mathrm{Pd}-\mathrm{N}(2)$ & & & $84.4(1)$ & $85.0(1)$ \\
$\mathrm{N}(1)-\mathrm{Pd}-\mathrm{C}(1)$ & $83.9(1)$ & $84.9(2)$ & $175.2(1)$ & \\
$\mathrm{N}(2)-\mathrm{Pd}-\mathrm{C}(1)$ & $175.4(1)$ & $175.5(3)$ & $91.1(1)$ & $176.98(7)$ \\
$\mathrm{N}(2)-\mathrm{Pd}-\mathrm{X}$ & $92.6(2)$ & $92.9(2)$ & $89.81(8)$ & $1.20(9)$ \\
$\mathrm{C}(1)-\mathrm{Pd}-\mathrm{X}$ & $177.9(1)$ & $175.8(2)$ & $121.7(2)$ & $122.5(2)$ \\
$\mathrm{Pd}-\mathrm{N}(2)-\mathrm{C}(4)$ & $88.0(2)$ & $88.7(2)$ & $114.3(3)$ & $108.1(3)$ \\
$\mathrm{Pd}-\mathrm{N}(2)-\mathrm{P}(1)$ & $126.9(2)$ & $124.3(4)$ & $120.5(5)$ & $128.0(2)$ \\
$\mathrm{P}(1)-\mathrm{N}(2)-\mathrm{C}(4)$ & $109.0(1)$ & $107.7(1)$ & $106.1(2)$ & $103.4(2)$ \\
$\mathrm{C}(22)-\mathrm{P}(1)-\mathrm{N}(2)$ & $123.8(2)$ & $126.6(2)$ & & \\
\hline
\end{tabular}

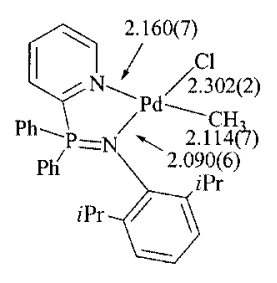

N-Pd-N $84.9(2)^{\circ}$

1c

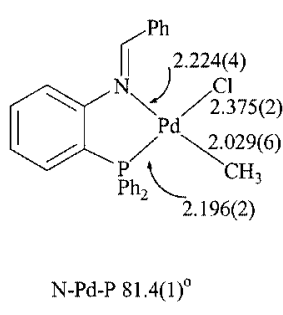

(P N)PdMeCl

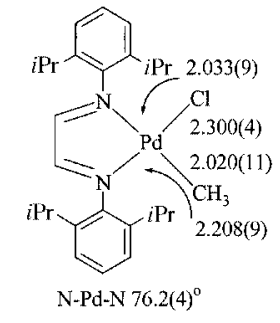

(N N)PdMeCl
Scheme 2. Summary of bond lengths and bond angles of palladium complexes

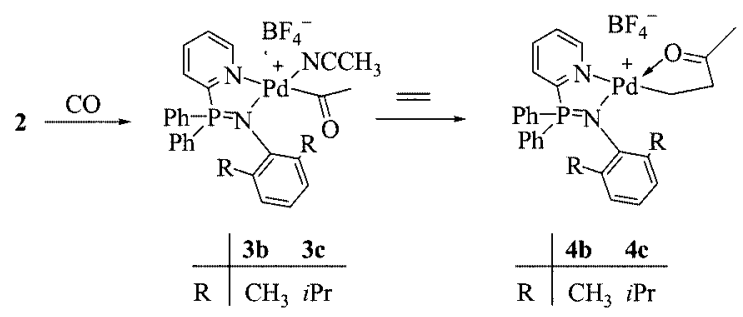

Scheme 3

Table 4. Selected spectroscopic data for $\mathbf{3 a}-\mathbf{c}$ and $\mathbf{4 b}-\mathbf{c}^{[\mathbf{a}]}$

\begin{tabular}{lllll}
\hline Complex & $\begin{array}{l}{ }^{1} \mathrm{H} \mathrm{NMR} \\
-\mathrm{CO}-\mathrm{CH}_{3}\end{array}$ & $\begin{array}{l}{ }^{13} \mathrm{C} \mathrm{NMR} \\
-C=\mathrm{O}\end{array}$ & ${ }^{31} \mathrm{P} \mathrm{NMR}$ & $\mathrm{IR}\left(v_{\mathrm{CO}}\right)^{[\mathrm{b}]}$ \\
\hline $\mathbf{3 a}$ & 2.14 & 221.5 & 22.0 & 1728 \\
$\mathbf{3 b}$ & 1.76 & 221.3 & 26.3 & 1713 \\
$\mathbf{3 c}$ & 1.79 & 220.9 & 24.6 & 1713 \\
$\mathbf{4 b}$ & 2.01 & 211.6 & 28.3 & 1623 \\
$\mathbf{4 c}$ & 1.77 & 224.2 & 29.8 & 1660 \\
\hline
\end{tabular}

${ }^{[a]}$ Chemical shifts in ppm, in $\mathrm{CDCl}_{3} \cdot{ }^{[\mathrm{b}]} \mathrm{KBr}, \mathrm{cm}^{-1}$.

simple substitution of $\left[\mathrm{PdCl}_{2}\left(\mathrm{CH}_{3} \mathrm{CN}\right)_{2}\right]$ with an equimolar amount of $\mathbf{L}_{\mathbf{b}}$. The complex was readily purified by recrystallization and the crystal structure was determined. Fig- ure 4 shows a perspective view of the complex whose selected bond lengths and bond angles are summarized in Table 3. As expected, complex 5 shows a square-planar coordination geometry around the metal center, with the $\mathrm{N}(1)-\mathrm{Pd}-\mathrm{N}(2)$ angle deviating slightly from $90^{\circ}$ because of the constraint imposed by the chelating ring. No major deviation was observed in the bond lengths and angles with respect to $\mathbf{1 b}, \mathbf{1 c}$ and $\mathbf{2 a}$. The lengths of both $\mathrm{Pd}-\mathrm{Cl}$ bonds are essentially identical. However, the $\mathrm{Pd}-\mathrm{N}(1)$ lengths in $\mathbf{1 b}, \mathbf{1 c}$ and $\mathbf{2 a}$ which is trans to the carbon donors, lie in the range of $2.16-2.17 \AA$, whereas the $\mathrm{Pd}-\mathrm{N}(1)$ distance in 5 is shorter by about $0.1 \AA$. This variation is due to the stronger trans influence of carbon versus chloride ligands. From this structural analysis, both nitrogen donors (pyridinyl and iminophosphorane) have a similar trans influence. However, the pyridinyl-nitrogen donor appears to be somewhat stronger due to the alkyl ligands being trans to the nitrogen ligand in complexes $\mathbf{1}$ and $\mathbf{2}$.

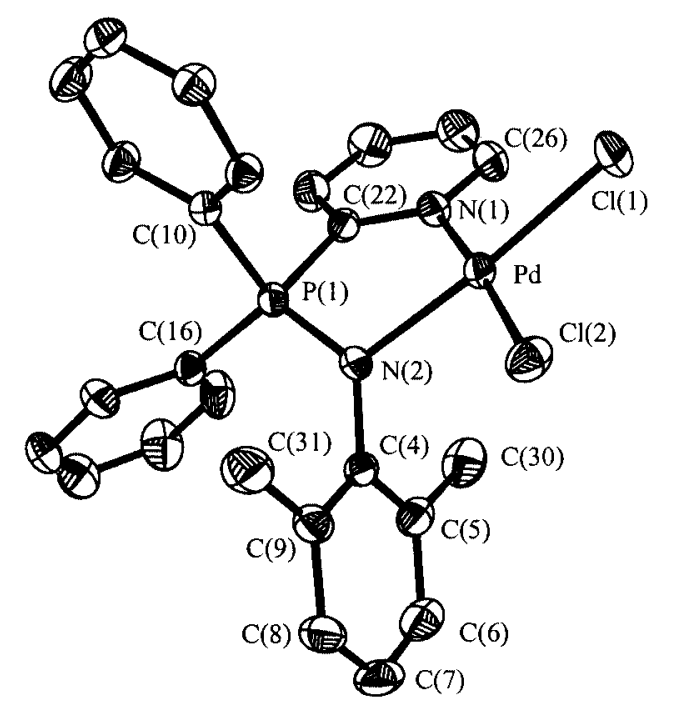

Figure 4. Molecular structure of palladium dichloride complex 5 


\section{Copolymerization}

The catalytic activity of the cationic palladium complexes $\mathbf{2 a}-\mathbf{c}$ was examined. Unlike the corresponding diiminopalladium complexes, ${ }^{[1]}$ this series of complexes were not good catalysts for the polymerization of ethylene. Nevertheless, complex $\mathbf{2 b}$ was found to catalyze the copolymerization of carbon monoxide and norbornene (Table 5). Both the chemical shift in the ${ }^{13} \mathrm{C}$ NMR spectrum and the infrared stretching frequency of the carbonyl group $(\delta=211 \mathrm{ppm}$ and $1713 \mathrm{~cm}^{-1}$ respectively) clearly demonstrate the formation of the copolymer. As shown in Table 5, the olefin concentration does not have any effect on either the molecular weight or the yield. However, a higher pressure of carbon monoxide led to the precipitation of palladium black out of solution and to lower molecular weight copolymers. In terms of solvent effect, both a coordinating solvent such as acetonitrile (entry 6) and a non-polar solvent (entry 8) provide poor conversions. By comparing the catalysts (entries 1, 7 and 9), complex $\mathbf{2 b}$ appears to be much more active than either $\mathbf{2 a}$ or $\mathbf{2 c}$. The lower activity of $\mathbf{2} \mathbf{c}$ is presumably due to the steric hindrance of the ligand, whereas in the case of $\mathbf{2 a}$ it is due to the lower stability of the inserted intermediates as illustrated in the previous section. In terms of the catalytic copolymerization of $\mathrm{CO} /$ norbornene, complex 2b shows a similar activity to that of $\left[\mathrm{PdMe}(\mathbf{P} \sim \mathbf{N})\left(\mathrm{CH}_{3} \mathrm{CN}\right)\right] \mathrm{BF}_{4} \cdot{ }^{[13 \mathrm{a}]}$

Table 5. Results of copolymerization of $\mathrm{CO}$ and norbornene ${ }^{[\mathrm{a}]}$

\begin{tabular}{llllll}
\hline Entry & $\mathrm{CO}(\mathrm{psi})$ & $M_{\mathrm{N}}$ & PDI & Yield & $\mathrm{TOF}^{[\mathrm{b}]}$ \\
\hline 1 & 14.7 & 5746 & 1.50 & $311 \mathrm{mg}$ & 24 \\
2 & 200 & 3288 & 1.93 & $204 \mathrm{mg}$ & 16 \\
3 & 14.7 & 5137 & 1.37 & $251 \mathrm{mg}$ & 19 \\
4 & 200 & 2352 & 1.51 & $254 \mathrm{mg}$ & 20 \\
5 & 50 & 2373 & 1.43 & $216 \mathrm{mg}$ & 17 \\
$6^{[\mathrm{c}]}$ & 14.7 & 2902 & 1.58 & $125 \mathrm{mg}$ & 10 \\
$7^{[\mathrm{d}]}$ & 14.7 & 2485 & 1.63 & $187 \mathrm{mg}$ & 14 \\
$8^{[\mathrm{e}]}$ & 150 & $-[\mathrm{f}]$ & - & $76 \mathrm{mg}$ & 5.9 \\
$9^{[\mathrm{g}]}$ & 14.7 & 1976 & 1.61 & $173 \mathrm{mg}$ & 13 \\
\hline
\end{tabular}

[a] Catalyst: $2 \mathbf{b}$ (30 mg), norbornene (5 g), $24 \mathrm{~h}$, in $\mathrm{CH}_{2} \mathrm{Cl}_{2}(20 \mathrm{~mL})$ at $30{ }^{\circ} \mathrm{C}$ except where noted; norbornene $(10 \mathrm{~g})$ was used in entries 3 and 4. ${ }^{[\mathrm{b}]} \mathrm{g} \cdot \mathrm{mol}^{-1} \cdot \mathrm{h}^{-1}{ }^{[\mathrm{c}]} \mathrm{In} \mathrm{CH}_{2} \mathrm{Cl}_{2} / \mathrm{CH}_{3} \mathrm{CN}=4: 1$. [d] $\mathbf{2 a}$ as the catalyst. ${ }^{[\mathrm{e}]}$ In toluene. ${ }^{[\mathrm{f}]} M_{\mathrm{N}}$ was not determined due to its poor solubility in organic solvent. ${ }^{[\mathrm{g}]} \mathbf{2 c}$ as the catalyst.

In addition to the copolymerization of $\mathrm{CO} /$ norbornene, this series of complexes can also copolymerize ethylene and norbornene. In a typical reaction, $\mathbf{2 b}(30 \mathrm{mg})$ was added to norbornene and ethylene (500 psi) in toluene $(20 \mathrm{~mL})$ at 30 ${ }^{\circ} \mathrm{C}$ and after 24 hours, $1.4 \mathrm{~g}$ of copolymer was produced. The results are summarized in Table 6 . The appropriate reaction conditions for this polymerization appear in entry 4 with the ratio of norbornene to ethylene being 55:45. The mol percentage of the incorporated norbornene units was determined by the glass transition point $\left(T_{\mathrm{g}}\right)$ method devel- oped by Ruchatz and Fink. ${ }^{[14]}$ Among these catalysts (entries 4-6), complex $\mathbf{2 b}$ appears to be the one with the highest activity. On the other hand, the phosphanylimine palladium complex $\left[\mathrm{PdMe}\left(\mathrm{CH}_{3} \mathrm{CN}\right)(\mathbf{P} \sim \mathbf{N})\right] \mathrm{BF}_{4}$ does not show this kind of activity.

Table 6. Results of copolymerization of ethylene/norbornene $\mathrm{e}^{[\mathrm{a}]}$

\begin{tabular}{llllllllrr}
\hline Entry norbornene & $\begin{array}{l}\text { Time } \\
(\mathrm{h})\end{array}$ & $M_{\mathrm{N}}$ & PDI $\begin{array}{l}\text { Yield } \\
(\mathrm{mg})\end{array}$ & $\begin{array}{l}\left.\mathrm{N} \%{ }^{[\mathrm{b}]}\right] \\
\left(^{\circ} \mathrm{C}\right)\end{array}$ & $\mathrm{TOF}^{[\mathrm{c}]}$ \\
\hline 1 & 2.5 & 24 & 31000 & 1.41 & 1431 & 54.2 & 141.8 & 110 \\
$2^{[\mathrm{d}]}$ & 5.0 & 48 & 20000 & 1.75 & 1114 & 61.9 & 130.2 & 43 \\
3 & 5.0 & 48 & 34000 & 1.61 & 2378 & 49.8 & 144.3 & 92 \\
4 & 5.0 & 24 & 35000 & 1.59 & 1772 & 55.5 & 126.6 & 137 \\
$5^{[\mathrm{e}]}$ & 5.0 & 24 & 3600 & 1.87 & 538 & 64.0 & 154.5 & 45 \\
$6^{[\mathrm{f}]}$ & 5.0 & 24 & 2900 & 1.44 & 108 & 59.7 & 122.4 & 8 \\
\hline
\end{tabular}

[a] Ethylene/Norbornene (5 g) with $\mathbf{2 b}(30 \mathrm{mg})$ as catalyst in toluene $(20 \mathrm{~mL})$ at $30{ }^{\circ} \mathrm{C}$ unless noted. ${ }^{[b]} \mathrm{N} \%$ : mol percent of norbornene (by $\mathrm{T}_{\mathrm{g}}$ method). ${ }^{[\mathrm{c}]} \mathrm{g} \cdot \mathrm{mol}^{-1} \cdot \mathrm{h}^{-1}[\mathrm{~d}]$ Reaction temperature at $50{ }^{\circ} \mathrm{C}$. ${ }^{[\mathrm{e}]} \mathbf{2 a}$ as the catalyst. ${ }^{[\mathrm{f}]} \mathbf{2} \mathbf{c}$ as the catalyst.

In summary, a series of pyridinyliminophosphorane ligands with different steric influences was prepared and their methylpalladium complexes appear to be stable toward moisture. As for the reactivity toward insertion of $\mathrm{CO}$ and ethylene, complexes $\mathbf{2} \mathbf{b}-\mathbf{c}$ with a sterically hindered environment can stabilize the inserted intermediates, but not 2a. As for catalysis, complex $\mathbf{2} \mathbf{b}$ is a good candidate for the coplymerization of $\mathrm{CO} /$ norbornene and ethylene/norbornene.

\section{Experimental Section}

General Information: NMR spectra were recorded in $\mathrm{CDCl}_{3}$ or $\left[D_{6}\right]$ acetone on either a Bruker AC-E 200 or AM-300 spectrometer. Chemical shifts are given in parts per million relative to $\mathrm{SiMe}_{4}$ for ${ }^{1} \mathrm{H}$ and ${ }^{13} \mathrm{C} \mathrm{NMR}$, and $85 \% \mathrm{H}_{3} \mathrm{PO}_{4}$ for ${ }^{31} \mathrm{P} \mathrm{NMR}$ spectroscopy. Due to the complication of the aromatic region, chemical shifts of non-aromatic carbons are reported. Infrared spectra were measured on a Nicolet Magna-IR 550 spectrometer (Series-II) as KBr pellets, unless otherwise noted. Gel permeation chromatography (GPC) data were obtained from a Waters Model 590 liquid chromatograph installed with a Lab Alliance RI 2000 detector using THF as eluent at room temperature and the polystyrene calibration curve for analyses. Differential scanning calorimetric (DSC) measurement was carried out on a TA 2920 system.

All reaction, manipulation and purification steps were performed under a dry nitrogen atmosphere. Tetrahydrofuran was distilled under nitrogen from sodium benzophenone ketyl. Dichloromethane and acetonitrile were dried with $\mathrm{CaH}_{2}$ and distilled under nitrogen. Other chemicals and solvents were of analytical grade and were used as received unless otherwise stated. 2-Diphenylphosphanylpyridine was prepared by reacting lithium diphenylphosphide with 2bromopyridine. ${ }^{[15]}$ Phenyl azide and 2,6-dialkylphenyl azide were obtained by the diazotization of the corresponding aniline followed by the substitution of azide anion. ${ }^{[16]}$ 
General Procedure for the Preparation of Ligands $\mathbf{L}_{\mathbf{a}}-\mathbf{L}_{\mathbf{c}}$ : 2-Diphenylphosphanylpyridine $(0.5 \mathrm{~g}, 1.9 \mathrm{mmol})$ and dichloromethane $(15 \mathrm{~mL})$ were placed in a degassed round-bottomed flask. A solution of aryl azide $(1.9 \mathrm{mmol})$ was transferred into the above flask under nitrogen. Nitrogen gas was generated immediately and the resulting mixture was stirred for $2.5 \mathrm{~h}$. After concentration, the desired ligands were obtained as moisture-sensitive, viscous liquids.

Ligand $\mathbf{L}_{\mathbf{a}}:(0.65 \mathrm{~g}, 96 \%),{ }^{1} \mathrm{H}$ NMR $\left(\mathrm{CDCl}_{3}\right): \delta=8.78(\mathrm{~d}, J=$ $4.6 \mathrm{~Hz}, 1 \mathrm{H}$, py- $\left.\mathrm{H}_{6}\right), 8.34\left(\mathrm{dd}, J=7.1,6.1 \mathrm{~Hz}, 1 \mathrm{H}\right.$, py- $\left.\mathrm{H}_{4}\right)$, 7.99-7.94 (m, 4 H, Ar-H), 7.78-7.76 (m, 1 H, py-H), 7.51-7.35 (m, $7 \mathrm{H}, \mathrm{Ar}-\mathrm{H}$, py-H), 7.07 (dd, $J=9.0,8.4 \mathrm{~Hz}, 2 \mathrm{H}, \mathrm{Ar}-\mathrm{H}), 6.90$ (d, $J=8.4 \mathrm{~Hz}, 2 \mathrm{H}, \mathrm{Ar}-\mathrm{H}), 6.71(\mathrm{t}, J=9.0 \mathrm{~Hz}, 1 \mathrm{H}, \mathrm{Ar}-\mathrm{H}) \mathrm{ppm}$. ${ }^{13} \mathrm{C}$ NMR: $\delta=155.2\left(\mathrm{~d}, J_{\mathrm{C}, \mathrm{P}}=130.0 \mathrm{~Hz}\right), 150.2\left(\mathrm{~d}, J_{\mathrm{C}, \mathrm{P}}=\right.$ $19.1 \mathrm{~Hz}), 140.0,136.2\left(\mathrm{~d}, J_{\mathrm{C}, \mathrm{P}}=9.0 \mathrm{~Hz}\right), 133.0\left(\mathrm{~d}, J_{\mathrm{C}, \mathrm{P}}=9.3 \mathrm{~Hz}\right)$, $131.7\left(\mathrm{~d}, J_{\mathrm{C}, \mathrm{P}}=2.7 \mathrm{~Hz}\right), 130.8,129.3\left(\mathrm{~d}, J_{\mathrm{C}, \mathrm{P}}=19.8 \mathrm{~Hz}\right), 128.7$, $128.5\left(\mathrm{~d}, J_{\mathrm{C}, \mathrm{P}}=11.9 \mathrm{~Hz}\right), 125.1\left(\mathrm{~d}, J_{\mathrm{C}, \mathrm{P}}=3.0 \mathrm{~Hz}\right), 123.4\left(\mathrm{~d}, J_{\mathrm{C}, \mathrm{P}}=\right.$ $18.2 \mathrm{~Hz}$ ), 117.4 ppm. ${ }^{31} \mathrm{P}$ NMR: $\delta=14.8$ ppm. HRMS (EI): calcd. for $\mathrm{C}_{23} \mathrm{H}_{19} \mathrm{~N}_{2} \mathrm{P} m / z=354.1286$; found: 354.1277. $\mathrm{C}_{23} \mathrm{H}_{19} \mathrm{~N}_{2} \mathrm{P}$ (354.38): calcd. C 77.95, H 5.40; found C 77.59, H 5.38.

Ligand $\mathbf{L}_{\mathbf{b}}:(0.68 \mathrm{~g}, 93 \%),{ }^{1} \mathrm{H}$ NMR $\left(\mathrm{CDCl}_{3}\right): \delta=8.75(\mathrm{~d}, J=$ $4.8 \mathrm{~Hz}, 1 \mathrm{H}$, py- $\left.\mathrm{H}_{6}\right), 8.38\left(\mathrm{dd}, J=7.0,6.2 \mathrm{~Hz}, 1 \mathrm{H}\right.$, py- $\left.\mathrm{H}_{4}\right)$, 7.80-7.75 (m, 5 H, Ar-H), 7.50-7.48 (m, $2 \mathrm{H}$, py-H), 7.43-7.36 (m, $5 \mathrm{H}, \mathrm{Ar}-\mathrm{H}), 6.95-6.93(\mathrm{~d}, J=7.0 \mathrm{~Hz}, 2 \mathrm{H}, \mathrm{Ar}-\mathrm{H}), 6.68(\mathrm{t}, J=$ $7.0 \mathrm{~Hz}, 1 \mathrm{H}, \mathrm{Ar}-\mathrm{H}), 2.07$ (s, $\left.6 \mathrm{H}, \mathrm{Ar}-\mathrm{CH}_{3}\right) \mathrm{ppm} .{ }^{13} \mathrm{C} \mathrm{NMR}: \delta=$ $157.2\left(\mathrm{~d}, J_{\mathrm{C}, \mathrm{P}}=133.8 \mathrm{~Hz}\right), 149.8\left(\mathrm{~d}, J_{\mathrm{C}, \mathrm{P}}=20.1 \mathrm{~Hz}\right), 146.6,136.1$ $\left(\mathrm{d}, J_{\mathrm{C}, \mathrm{P}}=8.9 \mathrm{~Hz}\right), 132.8\left(\mathrm{~d}, J_{\mathrm{C}, \mathrm{P}}=6.4 \mathrm{~Hz}\right), 132.5\left(\mathrm{~d}, J_{\mathrm{C}, \mathrm{P}}=\right.$ $9.2 \mathrm{~Hz}), 131.3\left(\mathrm{~d}, J_{\mathrm{C}, \mathrm{P}}=2.3 \mathrm{~Hz}\right), 128.2\left(\mathrm{~d}, J_{\mathrm{C}, \mathrm{P}}=12.0 \mathrm{~Hz}\right), 127.8$, 128.5, 124.8, 123.3, 119.0, 21.4 ppm. ${ }^{31} \mathrm{P}$ NMR: $\delta=16.5 \mathrm{ppm}$. HRMS calcd. for $\mathrm{C}_{25} \mathrm{H}_{23} \mathrm{~N}_{2} \mathrm{P} \mathrm{m} / z=382.1599$; found 382.1596 . $\mathrm{C}_{25} \mathrm{H}_{23} \mathrm{~N}_{2} \mathrm{P}$ (382.44): calcd. C 78.51, H 6.06; found C 78.22, H 5.79.

Ligand $\mathbf{L}_{\mathrm{c}}:(0.91 \mathrm{~g}, 91 \%),{ }^{1} \mathrm{H}$ NMR $\left(\mathrm{CDCl}_{3}\right): \delta=8.84(\mathrm{~d}, J=$ $4.0 \mathrm{~Hz}, 1 \mathrm{H}$, py-H 6 ), 7.59-7.41 (m, $7 \mathrm{H}$, py-H, Ar-H), 7.24-7.17 (m, $6 \mathrm{H}$, py-H, Ar-H), 7.09-6.98 (m, 3 H, Ar-H), 3.40-3.33 (m, $2 \mathrm{H},-\mathrm{CH}-), 1.41$ (d, $\left.J=6.9 \mathrm{~Hz}, 6 \mathrm{H},-\mathrm{CH}_{3}\right), 1.09(\mathrm{~d}, J=6.7 \mathrm{~Hz}$, $\left.6 \mathrm{H},-\mathrm{CH}_{3}\right) \mathrm{ppm} .{ }^{13} \mathrm{C} \mathrm{NMR}: \delta=156.8\left(\mathrm{~d}, J_{\mathrm{C}, \mathrm{P}}=132.3 \mathrm{~Hz}\right), 150.1$ $\left(\mathrm{d}, J_{\mathrm{C}, \mathrm{P}}=20.0 \mathrm{~Hz}\right), 143.2\left(\mathrm{~d}, J_{\mathrm{C}, \mathrm{P}}=4.9 \mathrm{~Hz}\right), 140.4,136.2\left(\mathrm{~d}, J_{\mathrm{C}, \mathrm{P}}=\right.$ $8.9 \mathrm{~Hz}), 134.4,132.7\left(\mathrm{~d}, J_{\mathrm{C}, \mathrm{P}}=9.1 \mathrm{~Hz}\right), 128.4\left(\mathrm{~d}, J_{\mathrm{C}, \mathrm{P}}=11.9 \mathrm{~Hz}\right)$, 127.1, 125.1, 124.2, 123.2, 118.8, 29.0 (-CH-), $23.8\left(-\mathrm{CH}_{3}\right), 22.7$ ($\mathrm{CH}_{3}$ ) ppm. ${ }^{31} \mathrm{P}$ NMR: $\delta=15.6$ ppm. HRMS calcd. for $\mathrm{C}_{29} \mathrm{H}_{31} \mathrm{~N}_{2} \mathrm{P}$ $m / z=438.2225$; found 438.2233. $\mathrm{C}_{29} \mathrm{H}_{31} \mathrm{~N}_{2} \mathrm{P}$ (438.54): calcd. $\mathrm{C}$ 79.42, H 7.12; found C 79.02, H 6.89.

General Procedure for the Preparation of $\left[\mathrm{L}_{\mathbf{X}} \mathrm{PdCIMe}\right](1 \mathrm{a}-\mathrm{c})$ : A mixture of $[\mathrm{PdClMe}(\mathrm{COD})](0.5 \mathrm{~g}, 1.89 \mathrm{mmol})$ with an equimolar amount of ligand in dichloromethane $(5 \mathrm{~mL})$ was stirred at room temperature under a nitrogen atmosphere. After stirring for $3 \mathrm{~h}$, the solvents were evaporated and the remaining material was dissolved in dichloromethane. Pre-dried diethyl ether was slowly added to the above solution to precipitate the desired complexes as yellow solids.

Complex 1a: $(0.71 \mathrm{~g}, 74 \%)$. M.p. $180-196{ }^{\circ} \mathrm{C}(\mathrm{dec}) .{ }^{1} \mathrm{H}$ NMR $\left(\mathrm{CDCl}_{3}\right): \delta=9.39\left(\mathrm{~d}, J=4.5 \mathrm{~Hz}, 1 \mathrm{H}, \mathrm{py}-\mathrm{H}_{6}\right), 7.84-7.81(\mathrm{~m}, 1$ $\mathrm{H}$, py-H), 7.76-7.64 (m, 6 H, py-H, Ar-H), 7.57-7.51 (m, $5 \mathrm{H}$, Ar-H), 7.36 (m, $1 \mathrm{H}$, py-H), 6.99-6.93 (m, $4 \mathrm{H}, \mathrm{Ar}-\mathrm{H}), 6.80-6.76$ (m, $1 \mathrm{H}, \mathrm{Ar}-\mathrm{H}), 0.77$ (s, $\left.3 \mathrm{H}, \mathrm{Pd}-\mathrm{CH}_{3}\right)$ ppm. ${ }^{13} \mathrm{C}$ NMR: $\delta=153.8$ $\left(\mathrm{d}, J_{\mathrm{C}, \mathrm{P}}=143.9 \mathrm{~Hz}\right), 151.0\left(\mathrm{~d}, J_{\mathrm{C}, \mathrm{P}}=12.8 \mathrm{~Hz}\right), 145.9,137.4(\mathrm{~d}$, $\left.J_{\mathrm{C}, \mathrm{P}}=10.2 \mathrm{~Hz}\right), 133.7133 .3,\left(\mathrm{~d}, J_{\mathrm{C}, \mathrm{P}}=10.3 \mathrm{~Hz}\right), 129.3\left(\mathrm{~d}, J_{\mathrm{C}, \mathrm{P}}=\right.$ $11.2 \mathrm{~Hz}), 128.0,127.2\left(\mathrm{~d}, J_{\mathrm{C}, \mathrm{P}}=9.8 \mathrm{~Hz}\right), 126.9,125.2$, (d, $J_{\mathrm{C}, \mathrm{P}}=$ $9.2 \mathrm{~Hz}), 121.8,-3.0$ (s, Pd-CH ${ }_{3}$ ) ppm. ${ }^{31} \mathrm{P}$ NMR: $\delta=26.56 \mathrm{ppm}$. $\mathrm{C}_{24} \mathrm{H}_{22} \mathrm{ClN}_{2} \mathrm{PPd}$ (511.29): calcd. C 56.38, H 4.34, N 5.48; found $\mathrm{C}$ $56.72, \mathrm{H} 4.34, \mathrm{~N} 5.40$.

Complex 1b: $\left(0.8\right.$ g, 79\%). M.p. $185-210{ }^{\circ} \mathrm{C}$ (dec). ${ }^{1} \mathrm{H}$ NMR $\left(\mathrm{CDCl}_{3}\right): \delta=9.35\left(\mathrm{~d}, J=5.1 \mathrm{~Hz}, 1 \mathrm{H}, \mathrm{py}-\mathrm{H}_{6}\right), 7.87-7.82(\mathrm{~m}, 5$
H, Ar-H), 7.57-7.55 (m, 2 H, py-H), 7.48-7.24 (m, 6 H, Ar-H, py-H), 6.75-6.66 (m, $3 \mathrm{H}, \mathrm{Ar}-\mathrm{H}), 2.24$ (s, 3 H, Ar- $\left.\mathrm{CH}_{3}\right), 0.62$ (s, $\left.3 \mathrm{H}, \mathrm{Pd}-\mathrm{CH}_{3}\right) \mathrm{ppm} .{ }^{13} \mathrm{C} \mathrm{NMR}: \delta=154.4\left(\mathrm{~d}, J_{\mathrm{C}, \mathrm{P}}=134.5 \mathrm{~Hz}\right)$, $151.3\left(\mathrm{~d}, J_{\mathrm{C}, \mathrm{P}}=12.9 \mathrm{~Hz}\right), 143.1,137.4\left(\mathrm{~d}, J_{\mathrm{C}, \mathrm{P}}=9.52 \mathrm{~Hz}\right), 135.9$ $\left(\mathrm{d}, J_{\mathrm{C}, \mathrm{P}}=5.5 \mathrm{~Hz}\right), 133.4\left(\mathrm{~d}, J_{\mathrm{C}, \mathrm{P}}=2.8 \mathrm{~Hz}\right), 132.7\left(\mathrm{~d}, J_{\mathrm{C}, \mathrm{P}}=\right.$ $10.1 \mathrm{~Hz}), 129.1\left(\mathrm{~d}, J_{\mathrm{C}, \mathrm{P}}=12.5 \mathrm{~Hz}\right), 127.9\left(\mathrm{~d}, J_{\mathrm{C}, \mathrm{P}}=2.7 \mathrm{~Hz}\right), 126.9$ $\left(\mathrm{d}, J_{\mathrm{C}, \mathrm{P}}=2.7 \mathrm{~Hz}\right), 126.3\left(\mathrm{~d}, J_{\mathrm{C}, \mathrm{P}}=23.0 \mathrm{~Hz}\right), 125.3\left(\mathrm{~d}, J_{\mathrm{C}, \mathrm{P}}=\right.$ $95.0 \mathrm{~Hz}), 123.2\left(\mathrm{~d}, J_{\mathrm{C}, \mathrm{P}}=3.2 \mathrm{~Hz}\right), 21.9\left(\mathrm{~s}, \mathrm{Ar}_{-} \mathrm{CH}_{3}\right),-5.79(\mathrm{~s},-$ $\mathrm{PdCH}_{3}$ ) ppm. ${ }^{31} \mathrm{P}$ NMR: $\delta=21.70$ ppm. $\mathrm{C}_{26} \mathrm{H}_{26} \mathrm{ClN}_{2} \mathrm{PPd}$ (539.34): calcd. C 57.90, H 4.86, N 5.19; found C 57.39, H 4.86, N 5.20.

Complex 1c: $(0.86$ g, $76 \%)$. M.p. $183-190{ }^{\circ} \mathrm{C}(\mathrm{dec}) .{ }^{1} \mathrm{H}$ NMR $\left(\mathrm{CDCl}_{3}\right): \delta=9.47\left(\mathrm{~d}, J=5.0 \mathrm{~Hz}, 1 \mathrm{H}, \mathrm{py}-\mathrm{H}_{6}\right), 7.86-7.82(\mathrm{~m}, 1$ $\mathrm{H}$, py-H), 7.80-7.75 (m, $5 \mathrm{H}, \mathrm{Ar}-\mathrm{H}), 7.54-7.46$ (m, $5 \mathrm{H}, \mathrm{Ar}-\mathrm{H})$, 7.35-7.32 (m, $2 \mathrm{H}$, py-H), 6.95-6.84 (m, 3 H, Ar-H), 3.59-3.56 (m, $2 \mathrm{H},-\mathrm{CH}-), 1.34$ (d, $\left.J=6.7 \mathrm{~Hz}, 6 \mathrm{H},-\mathrm{CH}_{3}\right), 0.69$ (s, $3 \mathrm{H}, \mathrm{Pd}-$ $\left.\mathrm{CH}_{3}\right), 0.55$ (d, $\left.J=6.8 \mathrm{~Hz}, 6 \mathrm{H},-\mathrm{CH}_{3}\right) \mathrm{ppm} .{ }^{13} \mathrm{C}$ NMR: $\delta=154.2$ $\left(\mathrm{d}, J_{\mathrm{C}, \mathrm{P}}=136.6 \mathrm{~Hz}\right), 151.2\left(\mathrm{~d}, J_{\mathrm{C}, \mathrm{P}}=12.6 \mathrm{~Hz}\right), 146.1\left(\mathrm{~d}, J_{\mathrm{C}, \mathrm{P}}=\right.$ $5.5 \mathrm{~Hz}), 139.4\left(\mathrm{~d}, J_{\mathrm{C}, \mathrm{P}}=2.1 \mathrm{~Hz}\right), 137.4\left(\mathrm{~d}, J_{\mathrm{C}, \mathrm{P}}=9.6 \mathrm{~Hz}\right), 133.2$ $\left(\mathrm{d}, J_{\mathrm{C}, \mathrm{P}}=2.2 \mathrm{~Hz}\right), 132.9\left(\mathrm{~d}, J_{\mathrm{C}, \mathrm{P}}=9.7 \mathrm{~Hz}\right), 129.0\left(\mathrm{~d}, J_{\mathrm{C}, \mathrm{P}}=\right.$ $12.2 \mathrm{~Hz}), 127.2,126.9,125.5\left(\mathrm{~d}, J_{\mathrm{C}, \mathrm{P}}=94.1 \mathrm{~Hz}\right), 124.1\left(\mathrm{~d}, J_{\mathrm{C}, \mathrm{P}}=\right.$ $2.9 \mathrm{~Hz}), 123.3\left(\mathrm{~d}, J_{\mathrm{C}, \mathrm{P}}=1.8 \mathrm{~Hz}\right), 28.3(-\mathrm{CH}-), 24.7(\mathrm{~s}, \mathrm{Ar}-$ $\left.\mathrm{CH}_{3}\right), 23.1\left(-\mathrm{CH}_{3}\right),-2.88\left(\mathrm{~s},-\mathrm{PdCH}_{3}\right)$ ppm. ${ }^{31} \mathrm{P}$ NMR: $\delta=22.50$ ppm. $\mathrm{C}_{30} \mathrm{H}_{34} \mathrm{ClN}_{2} \mathrm{PPd}$ (595.45): calcd. C 60.51, H 5.76, N4.70; found $\mathrm{C} 60.23, \mathrm{H} 5.68, \mathrm{~N} 4.73$.

General Procedure for the Synthesis of $\left[\mathrm{L}_{\mathbf{X}} \mathrm{PdMe}\left(\mathrm{CH}_{3} \mathrm{CN}\right)\right] \mathrm{BF}_{4}$ $(\mathbf{2 a}-\mathbf{c})$ : An acetonitrile solution of $\mathrm{AgBF}_{4}(0.19 \mathrm{~g}, 0.97 \mathrm{mmol})$ was added to a solution of $\mathrm{L}_{\mathrm{x}} \mathrm{PdClMe}(0.97 \mathrm{mmol})$ in dichloromethane $(10 \mathrm{~mL})$ under a nitrogen atmosphere. After stirring for $1 \mathrm{~h}$, removal of $\mathrm{AgCl}$ by filtration and concentration gave the crude product, which was recrystallized from dichloromethane and diethyl ether to provide the desired products as yellow solids.

Complex 2a: $(0.40 \mathrm{~g}, 66 \%)$. M.p. $121-132{ }^{\circ} \mathrm{C}(\mathrm{dec}) .{ }^{1} \mathrm{H}$ NMR $\left(\mathrm{CDCl}_{3}\right): \delta=9.03(\mathrm{~d}, J=4.7 \mathrm{~Hz}, 1 \mathrm{H}, \mathrm{py}-\mathrm{H}), 8.02-7.97(\mathrm{~m}, 1 \mathrm{H}$, py-H), $7.93-7.89$ (m, $1 \mathrm{H}$, py-H), 7.73-7.67 (m, 6 H, py-H, ArH), 7.59-7.53 (m, $5 \mathrm{H}, \mathrm{Ar}-\mathrm{H}), 6.96(\mathrm{dd}, J=7.6,6.2 \mathrm{~Hz}, 2 \mathrm{H}, \mathrm{Ar}-$ $\mathrm{H}), 6.87(\mathrm{~d}, J=7.6 \mathrm{~Hz}, 1 \mathrm{H}, \mathrm{Ar}-\mathrm{H}), 6.80(\mathrm{t}, J=6.2 \mathrm{~Hz}, 2 \mathrm{H}, \mathrm{Ar}-$ $\mathrm{H}), 2.44\left(\mathrm{~s}, 3 \mathrm{H},-\mathrm{NCCH}_{3}\right), 0.69$ (s, $\left.3 \mathrm{H}, \mathrm{Pd}-\mathrm{CH}_{3}\right) \mathrm{ppm} .{ }^{13} \mathrm{C} \mathrm{NMR}$ : $\delta=152.3\left(\mathrm{~d}, J_{\mathrm{C}, \mathrm{P}}=140.5 \mathrm{~Hz}\right), 152.3\left(\mathrm{~d}, J_{\mathrm{C}, \mathrm{P}}=12.7 \mathrm{~Hz}\right), 144.9$, $139.0\left(\mathrm{~d}, J_{\mathrm{C}, \mathrm{P}}=10.3 \mathrm{~Hz}\right), 134.3\left(\mathrm{~d}, J_{\mathrm{C}, \mathrm{P}}=2.9 \mathrm{~Hz}\right), 133.3\left(\mathrm{~d}, J_{\mathrm{C}, \mathrm{P}}=\right.$ $16.3 \mathrm{~Hz}), 129.6\left(\mathrm{~d}, J_{\mathrm{C}, \mathrm{P}}=12.5 \mathrm{~Hz}\right), 128.3,128.0\left(\mathrm{~d}, J_{\mathrm{C}, \mathrm{P}}=\right.$ $23.7 \mathrm{~Hz}), 127.4\left(\mathrm{~d}, J_{\mathrm{C}, \mathrm{P}}=8.9 \mathrm{~Hz}\right), 122.8,121.1,3.25\left(\mathrm{NCCH}_{3}\right)$, $1.12\left(\mathrm{~s}, \quad \mathrm{Pd}-\mathrm{CH}_{3}\right)$ ppm. ${ }^{31} \mathrm{P}$ NMR: $\delta=34.34$ ppm. $\mathrm{C}_{26} \mathrm{H}_{25} \mathrm{BF}_{4} \mathrm{~N}_{3} \mathrm{PPd}$ (603.70): calcd. C 51.73, H4.17, N 6.96; found C $51.75, \mathrm{H} 4.18, \mathrm{~N} 6.43$.

Complex 2b: (0.51 g, 84\%). M.p. $182-196{ }^{\circ} \mathrm{C}$ (dec). ${ }^{1} \mathrm{H}$ NMR $\left(\mathrm{CDCl}_{3}\right): \delta=9.02(\mathrm{~d}, J=5.1 \mathrm{~Hz}, 1 \mathrm{H}, \mathrm{py}-\mathrm{H}), 8.01-7.98(\mathrm{~m}, 1$ $\mathrm{H}$, py- $\left.\mathrm{H}_{4}\right), 7.90-7.88(\mathrm{~m}, 1 \mathrm{H}, \mathrm{py}-\mathrm{H}), 7.78-7.73$ (m, $\left.4 \mathrm{H}, \mathrm{Ar}-\mathrm{H}\right)$, 7.62-7.59 (m, $2 \mathrm{H}$, Ar-H), 7.56-7.54 (m, $1 \mathrm{H}$, py-H), 7.50-7.46 (m, $4 \mathrm{H}, \mathrm{Ar}-\mathrm{H}), 6.74-6.68$ (m, $3 \mathrm{H}, \mathrm{Ar}-\mathrm{H}), 2.42$ (s, $\left.3 \mathrm{H},-\mathrm{NCCH}_{3}\right)$, 2.14 (s, $\left.6 \mathrm{H}, \mathrm{Ar}-\mathrm{CH}_{3}\right), 0.55$ (s, $\left.3 \mathrm{H}, \mathrm{Pd}-\mathrm{CH}_{3}\right)$ ppm. ${ }^{13} \mathrm{C} \mathrm{NMR}: \delta=$ $152.6\left(\mathrm{~d}, J_{\mathrm{C}, \mathrm{P}}=132.8 \mathrm{~Hz}\right), 152.4\left(\mathrm{~d}, J_{\mathrm{C}, \mathrm{P}}=12.5 \mathrm{~Hz}\right), 142.2(\mathrm{~d}$, $\left.J_{\mathrm{C}, \mathrm{P}}=1.5 \mathrm{~Hz}\right), 139.2\left(\mathrm{~d}, J_{\mathrm{C}, \mathrm{P}}=9.4 \mathrm{~Hz}\right), 135.9\left(\mathrm{~d}, J_{\mathrm{C}, \mathrm{P}}=5.2 \mathrm{~Hz}\right)$, $134.0\left(\mathrm{~d}, J_{\mathrm{C}, \mathrm{P}}=2.7 \mathrm{~Hz}\right), 132.6\left(\mathrm{~d}, J_{\mathrm{C}, \mathrm{P}}=10.1 \mathrm{~Hz}\right), 129.3\left(\mathrm{~d}, J_{\mathrm{C}, \mathrm{P}}=\right.$ $12.3 \mathrm{~Hz}), 128.1\left(\mathrm{~d}, J_{\mathrm{C}, \mathrm{P}}=2.3 \mathrm{~Hz}\right), 127.4\left(\mathrm{~d}, J_{\mathrm{C}, \mathrm{P}}=22.5 \mathrm{~Hz}\right), 124.0$ $\left(\mathrm{d}, J_{\mathrm{C}, \mathrm{P}}=95.6 \mathrm{~Hz}\right), 124.0\left(\mathrm{~d}, J_{\mathrm{C}, \mathrm{P}}=3.0 \mathrm{~Hz}\right), 121.1,21.7(\mathrm{~s}, \mathrm{Ar}-$ $\left.\mathrm{CH}_{3}\right), 15.1\left(\mathrm{~s},-\mathrm{NCCH}_{3}\right), 3.2\left(\mathrm{~s}, \mathrm{Pd}-\mathrm{CH}_{3}\right) \mathrm{ppm} .{ }^{31} \mathrm{P} \mathrm{NMR}: \delta=30.33$ ppm. $\mathrm{C}_{28} \mathrm{H}_{29} \mathrm{BF}_{4} \mathrm{~N}_{3} \mathrm{PPd}$ (631.75): calcd. C 53.23, H 4.63, N 6.65; found C 53.42, H 4.48, N 6.46 .

Complex 2c: $(0.27$ g, $78 \%)$. M.p. $125-140{ }^{\circ} \mathrm{C}(\mathrm{dec}) .{ }^{1} \mathrm{H}$ NMR $\left(\mathrm{CDCl}_{3}\right): \delta=9.13\left(\mathrm{~d}, J=4.6 \mathrm{~Hz}, 1 \mathrm{H}, \mathrm{py}-\mathrm{H}_{6}\right), 8.00-7.99(\mathrm{~m}, 1$ $\mathrm{H}$, py-H), 7.93-7.92 (m, $1 \mathrm{H}$, py-H), $7.65-7.59$ (m, 6 H, py-H, 
Ar-H), 7.49-7.43 (m, 5 H, Ar-H), 6.90 (t, $J=6.8 \mathrm{~Hz}, 1 \mathrm{H}$, Ar$\mathrm{H}), 6.81(\mathrm{~d}, J=6.8 \mathrm{~Hz}, 2 \mathrm{H}, \mathrm{Ar}-\mathrm{H}), 3.29$ (m, $2 \mathrm{H},-\mathrm{CH}-), 2.42$ (s, $\left.3 \mathrm{H},-\mathrm{NCCH}_{3}\right), 1.22\left(\mathrm{~d}, J=6.7 \mathrm{~Hz}, 6 \mathrm{H},-\mathrm{CH}_{3}\right), 0.58(\mathrm{~s}, 3 \mathrm{H}, \mathrm{Pd}-$ $\left.\mathrm{CH}_{3}\right), 0.47\left(\mathrm{~d}, J=6.85 \mathrm{~Hz}, 6 \mathrm{H},-\mathrm{CH}_{3}\right)$ ppm. ${ }^{13} \mathrm{C} \mathrm{NMR}: \delta=152.5$ $\left(\mathrm{d}, J_{\mathrm{C}, \mathrm{P}}=134.6 \mathrm{~Hz}\right), 152.3\left(\mathrm{~d}, J_{\mathrm{C}, \mathrm{P}}=12.5 \mathrm{~Hz}\right), 146.2\left(\mathrm{~d}, J_{\mathrm{C}, \mathrm{P}}=\right.$ $5.4 \mathrm{~Hz}), 139.0\left(\mathrm{~d}, J_{\mathrm{C}, \mathrm{P}}=9.6 \mathrm{~Hz}\right), 138.4\left(\mathrm{~d}, J_{\mathrm{C}, \mathrm{P}}=2.7 \mathrm{~Hz}\right), 133.9(\mathrm{~d}$, $\left.J_{\mathrm{C}, \mathrm{P}}=2.6 \mathrm{~Hz}\right), 132.8\left(\mathrm{~d}, J_{\mathrm{C}, \mathrm{P}}=9.7 \mathrm{~Hz}\right), 129.3\left(\mathrm{~d}, J_{\mathrm{C}, \mathrm{P}}=12.2 \mathrm{~Hz}\right)$, $128.3\left(\mathrm{~d}, J_{\mathrm{C}, \mathrm{P}}=22.6 \mathrm{~Hz}\right), 125.0\left(\mathrm{~d}, J_{\mathrm{C}, \mathrm{P}}=2.8 \mathrm{~Hz}\right), 124.3\left(\mathrm{~d}, J_{\mathrm{C}, \mathrm{P}}=\right.$ $94.9 \mathrm{~Hz}), 123.6\left(\mathrm{~d}, J_{\mathrm{C}, \mathrm{P}}=2.2 \mathrm{~Hz}\right), 121.2,28.4(-\mathrm{CH}-), 24.5\left(-\mathrm{CH}_{3}\right)$, $23.0\left(-\mathrm{CH}_{3}\right), 3.19\left(\mathrm{NCCH}_{3}\right), 1.66\left(\mathrm{Pd}-\mathrm{CH}_{3}\right)$ ppm. ${ }^{31} \mathrm{P}$ NMR: $\delta=$ 31.72 ppm. $\mathrm{C}_{32} \mathrm{H}_{37} \mathrm{BF}_{4} \mathrm{~N}_{3} \mathrm{PPd}$ (687.85): calcd. C 55.88, H 5.42, N 6.11; found C 55.62, H 5.95, N 6.53.

General Procedure for the Synthesis of $\left[\mathrm{L}_{\mathbf{X}} \mathrm{Pd}(\mathrm{CO}-\right.$ $\left.\mathbf{M e})\left(\mathbf{C H}_{3} \mathbf{C N}\right)\right] \mathbf{B F}_{4}$ : Carbon monoxide was bubbled through an acetonitrile solution of $\left[\mathrm{L}_{X} \mathrm{PdMe}\left(\mathrm{CH}_{3} \mathrm{CN}\right)\right] \mathrm{BF}_{4}(0.9 \mathrm{mmol})$ for $20 \mathrm{~min}$. The resulting mixture was passed through celite and the filtrate was concentrated. The crude product was dissolved in dichloromethane and diethyl ether was added to precipitate the desired insertion products as yellow solids. These complexes readily decomposed due to decarbonylation.

Complex 3b: (31 mg, 52\%). IR (KBr): $\tilde{v}=1713 \mathrm{~cm}^{-1}\left(v_{\mathrm{CO}}\right) .{ }^{1} \mathrm{H}$ NMR $\left(\mathrm{CDCl}_{3}\right): \delta=8.94\left(\mathrm{~d}, J=5.4 \mathrm{~Hz}, 1 \mathrm{H}, \mathrm{py}-\mathrm{H}_{6}\right), 8.02-7.97$ (m, $1 \mathrm{H}$, py-H), 7.87-7.77 (m, 5 H, Ar-H), 7.64-7.63 (m, $2 \mathrm{H}$, pyH), 7.54-7.53 (m, 5 H, Ar-H), 6.72-6.68 (m, 3 H, Ar-H), 2.24 (s, $\left.6 \mathrm{H}, \mathrm{Ar}-\mathrm{CH}_{3}\right), 2.01\left(\mathrm{~s}, 3 \mathrm{H},-\mathrm{NCCH}_{3}\right), 1.77$ (s, $\left.3 \mathrm{H}, \mathrm{Pd}-\mathrm{CO}-\mathrm{CH}_{3}\right)$ ppm. ${ }^{13} \mathrm{C}$ NMR: $\delta=221.3(-\mathrm{CO}-), 152.4\left(\mathrm{~d}, J_{\mathrm{C}, \mathrm{P}}=129.2 \mathrm{~Hz}\right)$, $152.8\left(\mathrm{~d}, J_{\mathrm{C}, \mathrm{P}}=12.3 \mathrm{~Hz}\right), 143.2,139.5\left(\mathrm{~d}, J_{\mathrm{C}, \mathrm{P}}=9.2 \mathrm{~Hz}\right), 135.5(\mathrm{~d}$, $\left.J_{\mathrm{C}, \mathrm{P}}=5.2 \mathrm{~Hz}\right), 134.2,132.9\left(\mathrm{~d}, J_{\mathrm{C}, \mathrm{P}}=10.2 \mathrm{~Hz}\right), 129.5\left(\mathrm{~d}, J_{\mathrm{C}, \mathrm{P}}=\right.$ $12.6 \mathrm{~Hz}), 129.0,128.5,127.2\left(\mathrm{~d}, J_{\mathrm{C}, \mathrm{P}}=21.6 \mathrm{~Hz}\right), 124.3,123.9(\mathrm{~d}$, $\left.J_{\mathrm{C}, \mathrm{P}}=97.4 \mathrm{~Hz}\right), 30.5\left(\mathrm{NCCH}_{3}\right), 21.8\left(\mathrm{Ar}-\mathrm{CH}_{3}\right), 2.3\left(\mathrm{Pd}-\mathrm{CO}-\mathrm{CH}_{3}\right)$ ppm. ${ }^{31} \mathrm{P}$ NMR: $\delta=26.3$ ppm. HRFABMS: calcd. for $\left[\mathrm{M}-\mathrm{BF}_{4}\right.$ $\left.-\mathrm{CH}_{3} \mathrm{CN}\right] \mathrm{m} / z=531.0818$; found 531.0822.

Complex 3c: $(35 \mathrm{mg}, 59 \%)$. IR (KBr): $\tilde{v}=1713 \mathrm{~cm}^{-1}\left(v_{\mathrm{CO}}\right) ;{ }^{1} \mathrm{H}$ NMR $\left(\mathrm{CDCl}_{3}\right): \delta=8.91\left(\mathrm{~d}, J=4.8 \mathrm{~Hz}, 1 \mathrm{H}, \mathrm{py}-\mathrm{H}_{6}\right), 8.02-7.97$ (m, $1 \mathrm{H}$, py-H), $7.89-7.87$ (m, $1 \mathrm{H}, \mathrm{py}-\mathrm{H}), 7.72-7.67$ (m, $6 \mathrm{H}$, Ar$\mathrm{H}, \mathrm{py}-\mathrm{H}), 7.54-7.50(\mathrm{~m}, 5 \mathrm{H}, \mathrm{Ar}-\mathrm{H}), 6.93(\mathrm{t}, J=7.7 \mathrm{~Hz}, 1 \mathrm{H}, \mathrm{Ar}-$ $\mathrm{H}), 6.86(\mathrm{~d}, J=7.7 \mathrm{~Hz}, 1 \mathrm{H}, \mathrm{Ar}-\mathrm{H}), 3.38-3.30$ (m, $2 \mathrm{H},-\mathrm{CH}-)$, $2.19\left(\mathrm{~s}, 3 \mathrm{H},-\mathrm{NCCH}_{3}\right), 1.79\left(\mathrm{~s}, 3 \mathrm{H}, \mathrm{Pd}-\mathrm{CO}-\mathrm{CH}_{3}\right), 1.40(\mathrm{~d}, J=$ $\left.5.8 \mathrm{~Hz}, 6 \mathrm{H},-\mathrm{CH}_{3}\right), 0.59\left(\mathrm{~d}, J=6.8 \mathrm{~Hz}, 6 \mathrm{H},-\mathrm{CH}_{3}\right) \mathrm{ppm} .{ }^{13} \mathrm{C}$ NMR: $\delta=221.0(-\mathrm{CO}-), 152.6\left(\mathrm{~d}, J_{\mathrm{C}, \mathrm{P}}=128.5 \mathrm{~Hz}\right), 152.6(\mathrm{~d}$, $\left.J_{\mathrm{C}, \mathrm{P}}=13.1 \mathrm{~Hz}\right), 145.8\left(\mathrm{~d}, J_{\mathrm{C}, \mathrm{P}}=5.2 \mathrm{~Hz}\right), 139.6\left(\mathrm{~d}, J_{\mathrm{C}, \mathrm{P}}=3.8 \mathrm{~Hz}\right)$, $139.4\left(\mathrm{~d}, J_{\mathrm{C}, \mathrm{P}}=9.2 \mathrm{~Hz}\right), 134.2\left(\mathrm{~d}, J_{\mathrm{C}, \mathrm{P}}=2.5 \mathrm{~Hz}\right), 133.2\left(\mathrm{~d}, J_{\mathrm{C}, \mathrm{P}}=\right.$ $10.1 \mathrm{~Hz}), 129.5\left(\mathrm{~d}, J_{\mathrm{C}, \mathrm{P}}=12.6 \mathrm{~Hz}\right), 129.0,127.7\left(\mathrm{~d}, J_{\mathrm{C}, \mathrm{P}}=22 \mathrm{~Hz}\right)$, $125.1\left(\mathrm{~d}, J_{\mathrm{C}, \mathrm{P}}=2.7 \mathrm{~Hz}\right), 124.0\left(\mathrm{~d}, J_{\mathrm{C}, \mathrm{P}}=90.4 \mathrm{~Hz}\right), 124.0,31.30$ $\left(\mathrm{NCCH}_{3}\right), 28.7,24.2\left(-\mathrm{CH}_{3}\right), 23.62\left(-\mathrm{CH}_{3}\right), 2.15\left(\mathrm{Pd}-\mathrm{CO}-\mathrm{CH}_{3}\right)$ ppm. ${ }^{31} \mathrm{P}$ NMR: $\delta=24.7$ ppm. HRFABMS: calcd. for $\left[\mathrm{M}-\mathrm{BF}_{4}\right.$ $\left.-\mathrm{CH}_{3} \mathrm{CN}\right] \mathrm{m} / \mathrm{z}=587.1439$; found 587.1444.

General Procedure for the Synthesis of $\left[\mathrm{L}_{\mathrm{X}} \mathrm{Pd}\left(\mathrm{CH}_{2} \mathrm{CH}_{2} \mathrm{COMe}\right) \mathrm{BF}_{4}\right.$ : A solution of $\left[\mathrm{L}_{\mathrm{X}} \mathrm{Pd}(\mathrm{COMe})(\mathrm{CAN})\right] \mathrm{BF}_{4}$ in dichloromethane was bubbled through ethylene gas for $1.5 \mathrm{~h}$. The purification procedure was similar to that of $\left[\mathrm{L}_{X} \mathrm{Pd}(\mathrm{COMe})(\mathrm{CAN})\right] \mathrm{BF}_{4}$. The desired complexes were obtained as yellow solids.

Complex 4b: (38 mg, 65\%). M.p. $172-184{ }^{\circ} \mathrm{C}(\mathrm{dec}$.$) . IR (\mathrm{KBr}): \tilde{v}=$ $1623 \mathrm{~cm}^{-1}\left(v_{\mathrm{CO}}\right) .{ }^{1} \mathrm{H}$ NMR $\left(\mathrm{CDCl}_{3}\right): \delta=9.05(\mathrm{~d}, J=4.7 \mathrm{~Hz}, 1$ $\mathrm{H}$, py- $\left.\mathrm{H}_{6}\right), 8.24-8.22(\mathrm{~m}, 1 \mathrm{H}$, py-H), 8.07-8.04 (m, $1 \mathrm{H}$, py-H), $7.73-7.49$ (m, $11 \mathrm{H}$, py-H, Ar-H), 6.91-6.78 (m, 3 H, Ar-H), 2.26 (s, $\left.6 \mathrm{H}, \mathrm{Ar}-\mathrm{CH}_{3}\right), 2.11(\mathrm{~m}, 2 \mathrm{H}), 2.01\left(\mathrm{~s}, 3 \mathrm{H},-\mathrm{CH}_{3}\right), 1.88(\mathrm{~m}, 2 \mathrm{H})$ ppm. ${ }^{13} \mathrm{C}$ NMR: $\delta=211.6(-\mathrm{CO}-), 152.3\left(\mathrm{~d}, J_{\mathrm{C}, \mathrm{P}}=129.3 \mathrm{~Hz}\right)$, $151.3\left(\mathrm{~d}, J_{\mathrm{C}, \mathrm{P}}=21 \mathrm{~Hz}\right), 147.9,140.0\left(\mathrm{~d}, J_{\mathrm{C}, \mathrm{P}}=9.2 \mathrm{~Hz}\right), 137.4(\mathrm{~d}$, $\left.J_{\mathrm{C}, \mathrm{P}}=3.0 \mathrm{~Hz}\right), 135.1\left(\mathrm{~d}, J_{\mathrm{C}, \mathrm{P}}=2.7 \mathrm{~Hz}\right), 133.8\left(\mathrm{~d}, J_{\mathrm{C}, \mathrm{P}}=10.4 \mathrm{~Hz}\right)$, $129.5\left(\mathrm{~d}, J_{\mathrm{C}, \mathrm{P}}=12.9 \mathrm{~Hz}\right), 128.2\left(\mathrm{~d}, J_{\mathrm{C}, \mathrm{P}}=21.7 \mathrm{~Hz}\right), 128.0(\mathrm{~d}$,
$\left.J_{\mathrm{C}, \mathrm{P}}=3.1 \mathrm{~Hz}\right), 125.1\left(\mathrm{~d}, J_{\mathrm{C}, \mathrm{P}}=2.5 \mathrm{~Hz}\right), 123.8\left(\mathrm{~d}, J_{\mathrm{C}, \mathrm{P}}=2.8 \mathrm{~Hz}\right)$, $120.0\left(\mathrm{~d}, J_{\mathrm{C}, \mathrm{P}}=102.4 \mathrm{~Hz}\right), 37.9,30.1,19.9\left(\mathrm{Pd}-\mathrm{CO}-\mathrm{CH}_{3}\right) \mathrm{ppm} .{ }^{31} \mathrm{P}$ NMR: $\delta=28.4$ ppm. $\mathrm{C}_{29} \mathrm{H}_{30} \mathrm{BF}_{4} \mathrm{~N}_{2} \mathrm{OPPd}$ (646.76): calcd. $\mathrm{C} 53.85$, $\mathrm{H}$ 4.68, N 4.33; found C 53.53, H 4.38, N 4.21.

Complex 4c: $(37 \mathrm{mg}, 64 \%)$. M.p. $170-182{ }^{\circ} \mathrm{C}$ (dec.). IR (KBr): $\tilde{v}=$ $1660 \mathrm{~cm}^{-1}\left(v_{\mathrm{CO}}\right) ;{ }^{1} \mathrm{H}$ NMR $\left(\mathrm{CDCl}_{3}\right): \delta=8.81(\mathrm{~d}, J=4.3 \mathrm{~Hz}, 1$ $\mathrm{H}$, py-H $\left.{ }_{6}\right), 8.22-8.20$ (m, $1 \mathrm{H}$, py-H), 8.06-8.04 (m, $1 \mathrm{H}$, py-H), 7.65-7.51 (m, $11 \mathrm{H}$, py-H, Ar-H), 7.14-6.94 (m, 3 H, Ar-H), 3.01-2.96 (m, 2 H, -CH-), 2.27 (m, 2 H), 2.12 (m, 2 H), 1.77 (s, 3 $\left.\mathrm{H}, \mathrm{Pd}-\mathrm{OC}-\mathrm{CH}_{3}\right), 1.15$ (d, $\left.J=6.7 \mathrm{~Hz}, 3 \mathrm{H},-\mathrm{CH}_{3}\right), 0.75$ (d, $J=$ $\left.6.8 \mathrm{~Hz}, 3 \mathrm{H},-\mathrm{CH}_{3}\right) \mathrm{ppm} .{ }^{13} \mathrm{C} \mathrm{NMR:} \delta=224.3$, (-CO-), $151.3(\mathrm{~d}$, $\left.J_{\mathrm{C}, \mathrm{P}}=21.1 \mathrm{~Hz}\right), 147.9\left(\mathrm{~d}, J_{\mathrm{C}, \mathrm{P}}=3 \mathrm{~Hz}\right), 147.0\left(\mathrm{~d}, J_{\mathrm{C}, \mathrm{P}}=96.3 \mathrm{~Hz}\right)$, $139.7,138.1\left(\mathrm{~d}, J_{\mathrm{C}, \mathrm{P}}=10.5 \mathrm{~Hz}\right), 135.0\left(\mathrm{~d}, J_{\mathrm{C}, \mathrm{P}}=2.6 \mathrm{~Hz}\right), 134.0(\mathrm{~d}$, $\left.J_{\mathrm{C}, \mathrm{P}}=14.5 \mathrm{~Hz}\right), 131.2\left(\mathrm{~d}, J_{\mathrm{C}, \mathrm{P}}=24.3 \mathrm{~Hz}\right), 129.5\left(\mathrm{~d}, J_{\mathrm{C}, \mathrm{P}}=\right.$ $13.1 \mathrm{~Hz}), 128.1\left(\mathrm{~d}, J_{\mathrm{C}, \mathrm{P}}=3.6 \mathrm{~Hz}\right), 124.0,119.8\left(\mathrm{~d}, J_{\mathrm{C}, \mathrm{P}}=\right.$ 102.6 Hz), 119.6, 34.8, 29.7, 28.5, 24.7, 23.2, 19.7 (Pd-CO-CH $\left.{ }_{3}\right)$ ppm. ${ }^{31} \mathrm{P}$ NMR: $\delta=29.8$ ppm. $\mathrm{C}_{33} \mathrm{H}_{38} \mathrm{BF}_{4} \mathrm{~N}_{2} \mathrm{OPPd}$ (702.87): calcd. C 56.39, H 5.45, N 3.99; found C 55.98, H 5.14, N 3.78.

Complex 5: A mixture of 2,6-dimethylphenyl azide (0.223 g) and 2diphenylphosphanylpyridine $(0.4 \mathrm{~g})$ was placed in a degassed flask. Dichloromethane $(25 \mathrm{~mL})$ was introduced into the flask with a syringe under nitrogen atmosphere. The resulting mixture was stirred at room temperature for $2.5 \mathrm{~h}$. $\left[\mathrm{PdCl}_{2}(\mathrm{COD})\right](0.31 \mathrm{~g})$ in dichloromethane was added to the above solution. The reaction mixture turned yellow immediately. After concentration to a small volume, diethyl ether was slowly added and the desired product precipitated. The latter was then re-crystallized from diethyl ether/dichloromethane to provide 5 as a yellow solid $(765 \mathrm{mg}, 90 \%) .{ }^{1} \mathrm{H}$ $\operatorname{NMR}\left(\mathrm{CDCl}_{3}\right): \delta=8.74\left(\mathrm{~d}, J=4.4 \mathrm{~Hz}, 1 \mathrm{H}\right.$, py- $\left.\mathrm{H}_{6}\right), 8.38(\mathrm{~m}, 1$ $\left.\mathrm{H}, \mathrm{Py}-\mathrm{H}_{4}\right), 7.84-7.78$ (m, $\left.5 \mathrm{H}, \mathrm{Ar}-H\right), 7.64-7.62$ (m, $2 \mathrm{H}$, py-H), $7.51-7.46$ (m, $5 \mathrm{H}, \mathrm{Ar}-\mathrm{H}), 6.91-6.88$ (t, $J=7.4 \mathrm{~Hz}, 1 \mathrm{H}), 6.81$ (d, $J=7.4 \mathrm{~Hz}, 2 \mathrm{H}), 2.15\left(\mathrm{~s}, 6 \mathrm{H},-\mathrm{CH}_{3}\right) \mathrm{ppm} .{ }^{31} \mathrm{P}$ NMR: $\delta=28.42$ ppm. HRFABMS: Calcd for $\mathrm{C}_{25} \mathrm{H}_{23}{ }^{35} \mathrm{Cl}_{2} \mathrm{~N}_{2} \mathrm{PPd}: \mathrm{m} / z=558.0011$; found 558.0018. $\mathrm{C}_{25} \mathrm{H}_{23} \mathrm{Cl}_{2} \mathrm{~N}_{2} \mathrm{PPd}$ (559.76): calcd. C 53.64, $\mathrm{H} 4.14$, N 5.00; found C 53.29, H 3.78, N 4.89.

Copolymerization of $\mathrm{CO} /$ Norbornene: The catalysts and norbornene were placed into a stainless-steel autoclave $(100 \mathrm{~mL})$ and dissolved in the solvent $(20 \mathrm{~mL})$. The reaction mixture was then pressurized with a mixture of $\mathrm{CO}$ and stirred at $30^{\circ} \mathrm{C}$. The reaction was stopped after the specified time and the resulting white solid was filtered and washed with $5 \mathrm{~N} \mathrm{HCl}$ followed by water and acetone. The Results are listed in Table 5.

Copolymerization of Ethylene/Norbornene: The procedures for this coplymerization are similar to the ones of the copolymerization of $\mathrm{CO} /$ norbornene, except that ethylene is replaced by $\mathrm{CO}$. The results are summarized in Table 6.

X-ray Crystallographic Study: Crystals suitable for X-ray determination were obtained for $\mathbf{1 b}, \mathbf{1 c}, \mathbf{2} \mathbf{a} \cdot \mathrm{CH}_{2} \mathrm{Cl}_{2}$, and $\mathbf{5}$ by slow diffusion of diethyl ether into a dichloromethane solution at room temperature. The cell parameters were determined on a Siemens SMART CCD diffractometer. The crystal data for complexes $\mathbf{1 b}, \mathbf{1 c}$, $\mathbf{2 a} \cdot \mathrm{CH}_{2} \mathrm{Cl}_{2}$ and $\mathbf{5}$ are listed in Table 2 and their ORTEP plots are shown in Figures 1-4 respectively (labels of phenyl groups are omitted for clear view).

CCDC-210737 (1b), -210739 (1c), -210738 $\quad\left(\mathbf{2 a} \cdot \mathrm{CH}_{2} \mathrm{Cl}_{2}\right)$ and -210740 (5) contains the supplementary crystallographic data for this paper. These data can be obtained free of charge at www.ccdc.cam.ac.uk/conts/retrieving.html [or from the Cambridge Crystallographic Data Centre, 12, Union Road, Cambridge 
CB2 1EZ, UK; Fax: (internat.) +44-1223/336-033; E-mail: deposit@ccdc.cam.ac.uk].

\section{Acknowledgments}

We thank the National Science Council for financial support (NSC90-2113-M-002-038).

${ }^{[1]}$ [1a] L. K. Johnson, C. M. Killian, M. Brookhart, J. Am. Chem. Soc. 1995, 117, 6414-6415. [1b] C. M. Killian, D. J. Tempel, L. K. Johnson, M. Brookhart, J. Am. Chem. Soc. 1996, 118, 11664-11665. ${ }^{[1 \mathrm{c}]}$ D. J. Tempel, L. K. Johnson, R. L. Huff, P. S. White, M. Brookhart, J. Am. Chem. Soc. 2000, 122, 6686-6700. [1d] O. Daugulis, M. Brookhart, Organometallics 2002, 21, 5926-5934.

[2] Reviews on TM-catalyzed olefin polymerization: ${ }^{[2 \mathrm{a}]} \mathrm{S}$. D. Ittel, L. K. Johnson, M. Brookhart, Chem. Rev. 2000, 100, $1169-1203 .{ }^{[2 b]}$ E. Drent, P. H. M. Budzelaar, Chem. Rev. 1996, 96, 663-681. ${ }^{[2 \mathrm{c}]}$ G. Consiglio, Chimia 2001, 55, 809-813. [2d] Y. Imanishi, N. Naga, Prog. Polym. Sci. 2001, 26, 1147-1198. ${ }^{[2 \mathrm{e}]}$ C. Bianchini, A. Meli, Coord. Chem. Rev. 2002, 225, 35-66. [2f] J. Okuda, R. Mulhaupt, in Synthesis of Polymers (Ed.: A.D. Schlueter), Wiley-VCH Verlag $\mathrm{GmbH}$, Weinheim, Germany. 1999, Vol. 20, 123-162. ${ }^{[2 \mathrm{~g}]}$ A. Sen, Pure Appl. Chem. 2001, 73, 251-254. ${ }^{[2 \mathrm{~h}]}$ G. Helmchen, A. Pfaltz, Acc. Chem. Res. 2000, 33, 325-335. [2i] P. Braunstein, F. Naud, Angew. Chem. 2001, 113, 702-722; Angew. Chem. Int. Ed. 2001, 40, 680-699.

${ }^{[3]}$ H. Staudinger, E. Hauser, Helv. Chim. Acta 1921, 4, 887.

[4] [4a] A. Schmidpeter, T. von Criegern, Angew. Chem. 1978, 90, 64-65; Angew. Chem. Int. Ed. Engl. 1978, 17, 55-56. ${ }^{[4 \mathrm{~b}]} \mathrm{H}$. Alper, R. A. Partis, J. Organomet. Chem. 1972, 35, C40-C42. ${ }^{[4 c]}$ C.-Y. Liu, D.-Y. Chen, M.-C. Cheng, S.-M. Peng, S.-L. Liu, Organometallics 1995, 14, 1983-1991.

[5] [5a] W. Keim, R. Appel, A. Storeck, C. Kruger, R. Goddard, Angew. Chem. 1981, 93, 91-92; Angew. Chem. Int. Ed. Engl. 1981, 20, 116-117. ${ }^{[5 \mathrm{~b}]}$ M. Sauthier, F. Leca, R. Fernando de Souza, K. Bernardo-Gusmao, L. F. Trevisan Queiroz, L. Toupet, R. Réau, New J. Chem. 2002, 26, 630-635.

[6] [6a] N. Yue, E. Hollink, F. Guerin, D. W. Stephan, Organometallics 2001, 20, 4424-4433. ${ }^{[6 b]}$ N. L. S. Yue, D. W. Stephan, Organometallics 2001, 20, 2303-2308. [6c] J. E. Kickham, F. Guerin, J. C. Stewart, E. Urbanska, D. W. Stephan, Organometallics 2001, 20, 1175-1182. [6d] L. LePichon, D. W. Stephan, X. Gao, Q. Wang, Organometallics 2002, 21, 1362-1366. ${ }^{[6 \mathrm{e}]} \mathrm{L}$. LePichon, D. W. Stephan, Inorg. Chem. 2001, 40, 3827-3829. [6f] S. Courtenay, D. W. Stephan, Organometallics 2001, 20, $1442-1450$, and references therein.

[7] R. Vollmerhaus, P. Shao, N. J. Taylor, S. Collins, Organometallics 1999, 18, 2731-2733.

[8] M. Sauthier, J. Forniés-Cámer, L. Toupet, R. Réau, Organometallics 2000, 19, 553-562.

[9] [9a] J. Vicente, A. Arcas, D. Bautista, M. C. Ramirez de Arellano, Organometallics 1998, 17, 4544-4550. ${ }^{[9 b]}$ L. R. Falvello, S. Fernández, M. M. Garcia, R. Navarro, E. P. Urriolabeitia, J. Chem. Soc., Dalton Trans. 1998, 3745-3750. ${ }^{[9 c]}$ S. M. Aucott, A. M. Z. Slawin, J. D. Woollins, J. Chem. Soc., Dalton Trans. 2001, 2279-2287. ${ }^{[\mathrm{d}]}$ S. Al-Benna, M. J. Sarsfield, M. Thornton-Pett, D. L. Ormsby, P. J. Maddox, P. Bres, M. Bochmann, J. Chem. Soc., Dalton Trans. 2000, 4247-4257. ${ }^{[9 \mathrm{e}]} \mathrm{D}$. M. Hankin, A. A. Danopoulos, G. Wilkinson, T. K. N. Sweet, M. B. Hursthouse, J. Chem. Soc., Dalton Trans. 1996, 4063-4069. ${ }^{[9 f]}$ P. Imhoff, R. van Asselt, C. J. Elsevier, M. C. Zoutberg, C. H. Stam, Inorg. Chim. Acta 1991, 184, 73-87.

[10] [10a] K. V. Katti, B. D. Santarsiero, A. A. Pinkerton, R. G. Cavell, Inorg. Chem. 1993, 32, 5919-5925. ${ }^{[10 \mathrm{~b}]}$ R. W. Reed, B. Santarsiero, R. G. Cavell, Inorg. Chem. 1996, 35, 4292-4300.

${ }^{[11]}$ R. S. Pandurangi, K. V. Katti, L. Stillwell, C. L. Barnes, J. Am. Chem. Soc. 1998, 120, 11364-11373.

[12] [12a] M. W. Avis, C. J. Elsevier, N. Veldman, H. Kooijman, A. L. Spek, Inorg. Chem. 1996, 35, 1518-1528. ${ }^{[12 b]}$ M. W. Avis, C. J. Elsevier, H. Kooijman, N. Veldman, A. L. Spek, C. J. Elsevier, Inorg. Chem. 1995, 34, 4092-4105. [12c] M. W. Avis, K. Vrieze, J. M. Ernsting, C. J. Elsevier, N. Veldman, A. L. Spek, K. V. Katti, C. L. Barnes, Organometallics 1996, 15, 2376-2392. ${ }^{[12 \mathrm{~d}]}$ M. W. Avis, M. Goosen, C. J. Elsevier, N. Veldman, H. Kooijman, A. L. Spek, Inorg. Chim. Acta 1997, 264, 43-60

[13] [13a] K. R. Reddy, C.-L. Chen, Y.-H. Liu, S.-M. Peng, J.-T. Chen, S.-T. Liu, Organometallics 1999, 18, 2574-2576. ${ }^{[13 b]}$ K. R. Reddy; K. Surekha, G.-H. Lee, S.-M. Peng, J.-T. Chen, S.T. Liu, Organometallics 2001, 20, 1292-1299. [13c] Y.-C. Chen, C.-L. Chen, J.-T. Chen, S.-T. Liu, Organometallics 2001, 20, 1285-1286. ${ }^{[13 d]}$ K. R. Reddy, K. Surekha, G.-H. Lee, S.-M. Peng, S.-T. Liu, Organometallics 2001, 20, 5557-5563. [13e] P.Y. Shi, Y.-H. Liu, S.-M. Peng, S.-T. Liu, Organometallics 2002, 21, 3203-3207. ${ }^{[13 f]}$ K. R. Reddy, W. W. Tsai, K. Surekha, G.H. Lee, S.-M. Peng, J.-T. Chen, S.-T. Liu, J. Chem. Soc., Dalton Trans. 2002, 1776-1782.

${ }^{[14]}$ D. Ruchatz, G. Fink, Macromolecules 1998, 31, 4674-4680.

${ }^{[15]}$ T. J. Barder, F. A. Cotton, G. L. Powell, S. M. Tetrick, R. A. Walton, J. Am. Chem. Soc. 1984, 106, 1323-1332.

${ }^{[16]}$ I. Ugi, H. Perlinger, L. Behringer, Chem. Ber. 1958, 91, 2330.

Received March 6, 2003 